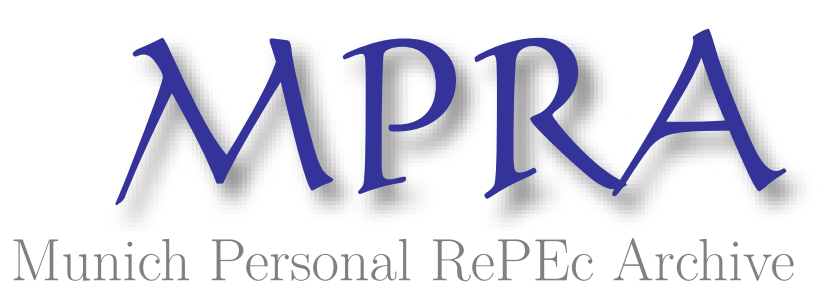

\title{
Crimes against property ownership
}

Zar Rokh, Ehsan and Radmanesh, Mansour

2007

Online at https://mpra.ub.uni-muenchen.de/8600/

MPRA Paper No. 8600, posted 06 May 2008 05:00 UTC 


\title{
Crimes against property \& ownership
}

\author{
Authors: Ehsan Zar Rokh＿zarrokh2007@yahoo.com \\ Mansour Radmanesh radmanesh.d@gmail.com \\ Abstract:
}

The most primeval crimes in all countries are crimes against property such as: Burglary, Larceny, Arson, Embezzlement, False pretenses, Extortion, forgery, fraud, robbery, and etc these crimes engender when ownership existed. Lord can do any possession in his/her property .If anyone trespasses to another one ownership prevailing law punishment him/her. Also we define these crimes in Islamic criminal law; because Islamic rules are strange and prober must study very hard to understand the principle of Islamic rules because most of them don't have reasonable source hence our definitions are so epitome because reader must study jurisprudence.

\section{Burglary}

Burglary - often just called breaking and entering - is a crime related to theft. It typically involves someone breaking into a house with intent to commit a crime. To carry out a burglary is to burgle (British English) or burglarize (US English).

Historical definition

The original common law definition of burglary consisted of six specific elements: "breaking and entering the dwelling of another during the night with the intention to commit a felony therein".

- Breaking

The first element, "breaking," required at least a minimal application of force. The opening of an unlocked door was sufficient, but if a person entered a house through an already open door or window, there were no "breaking" and therefore no burglary, even if all other elements were present. However, if a person were to enter the house through an open door, and were then to open a closed door leading to another room in the house, that would qualify as "breaking" into that room.

An exception to this rule applies where a person who had permission to enter the house did so at a time when they were not supposed to, or procured this permission by fraud or by threat. Under modern statutes, many jurisdictions have abandoned this element, now merely requiring entry.

\section{- Entering}

The second element, "entry" required that the person enter the house with some part of their body, even if only for a moment or that the person inserts a tool into the house for the purpose of committing the requisite felony. For example, firing a bullet through a closed window into someone's house with the intent to injure that person was sufficient to constitute both a breaking and an entry. Entry continues to be a requisite element of burglary in all jurisdictions.

(a) A person commits an offense if, without the effective consent of the owner, the person:

(1) Enters a habitation, or a building (or any portion of a building) not then open to the public, with intent to commit a felony, theft, or an assault; or

(2) Remains concealed, with intent to commit a felony, theft, or an assault, in a building or habitation; or 
(3) Enters a building or habitation and commits or attempts to commit a felony, theft, or an assault.

(b) For purposes of this section, "enter" means to intrude:

(1) Any part of the body; or

(2) Any physical object connected with the body.

(c) Except as provided in Subsection (d), an offense under this section is a:

(1) State jail felony if committed in a building other than a habitation; or

(2) Felony of the second degree if committed in a habitation.

(d) An offense under this section is a felony of the first degree if:

(1) The premises are a habitation; and

(2) Any party to the offense entered the habitation with intent to commit a felony other than felony theft or committed or attempted to commit a felony other than felony theft.

BURGLARY OF COIN-OPERATED OR COIN COLLECTION MACHINES

(a) A person commits an offense if, without the effective consent of

the owner, he breaks or enters into any coin-operated machine, coin collection machine, or other coin-operated or coin collection receptacle, contrivance, apparatus, or equipment used for the purpose of providing lawful amusement, sales of goods, services, or other valuable things, or telecommunications with intent to obtain property or services.

(b) For purposes of this section, "entry" includes every kind of entry except one made with the effective consent of the owner.

(c) An offense under this section is a Class A misdemeanor. BURGLARY OF VEHICLES

(a) A person commits an offense if, without the effective consent of the owner, he breaks into or enters a vehicle or any part of a vehicle with intent to commit any felony or theft.

(b) For purposes of this section, "enter" means to intrude:

(1) Any part of the body; or

(2) Any physical object connected with the body.

(c) For purposes of this section, a container or trailer carried on a rail car is a part of the rail car.

(d) An offense under this section is a Class A misdemeanor unless the vehicle or part of the vehicle broken into or entered is a rail car, in which event the offense is a state jail felony.

(e) It is a defense to prosecution under this section that the actor entered a rail car or any part of a rail car and was at that time an employee or a representative of employees exercising a right under the Railway Labor Act (45 U.S.C. Section 151 et seq.).

- Dwelling

The third element required that the crime be committed against a "dwelling" - a place where another person regularly slept (even if the structure was also used as a business, or was temporarily abandoned at the time). This requirement has also been largely abandoned under modern statutes, which now permit a burglary conviction to be based on the entry into almost any structure, and sometimes even entry to fenced yards and to automobiles.

Definitions of Habitation (Dwelling) 
(1) "Habitation" means a structure or vehicle that is adapted for the overnight accommodation of persons, and includes:

(A) Each separately secured or occupied portion of the structure or vehicle; and

(B) Each structure appurtenant to or connected with the structure or vehicle.

(2) "Building" means any enclosed structure intended for use or occupation as a habitation or for some purpose of trade, manufacture, ornament, or use.

(3) "Vehicle" includes any device in, on, or by which any person or property is or may be propelled, moved, or drawn in the normal course of commerce or transportation, except such devices as are classified as "habitation."

- Of another

The fourth element required that the dwelling be that of another person. A person could not burglarize their own dwelling, although a landlord could be found to have burglarized the dwelling of his tenant, even though the landlord was the owner of the property itself.

\section{- $\quad$ Nighttime}

The fifth element required that the burglary had to be committed at night, which was defined under the common law as the time when the person's face could not readily be distinguished under the natural light. Laws in many jurisdictions continue to impose much harsher penalties for burglaries committed or attempted at night, or upon an occupied residence.

- Intent to commit a felony

Finally, the sixth element required "intent to commit a felony therein." This intent had to exist at the time of the breaking and entering, even if the felony (e.g. murder, rape, larceny) was never carried out. If a person broke into a home and, once inside, decided to commit a felony, this would not constitute a burglary. The intent to commit a crime remains an element of all burglary laws, but some jurisdictions have expanded the list of requisite crimes beyond felonies to include any theft, even if it is a misdemeanor.

United States

In most jurisdictions in the United States, burglary is a felony and involves trespassing, or entering a building with intent to commit any crime, not necessarily a felony or theft. Thus, a conviction for burglary may qualify as a conviction under a three strikes law or habitual criminal statute, even though only something of low value or nothing at all was stolen. As with all legal definitions in the U.S., the foregoing description may not be applicable in every jurisdiction since there are 51 separate criminal codes in force.

The state of Massachusetts is somewhat unique in that it does not formally use the term "burglary;" instead, the acts of breaking and entering and any theft that occurs coincident with such entry are treated as separate offenses, with the former being officially denoted "breaking and entering in the nighttime (or daytime, as applicable) with intent to commit a felony (or misdemeanor, as applicable)," and the latter "(grand or petit) larceny from a building," if any property was indeed stolen. Thus if the perpetrator's intended act after entering the burglarized premises was not a felony, the result can be two different misdemeanor charges rather than a felony count.

Many other U.S. states treat burglary as a more serious crime when it occurs at night; California formerly prosecuted nighttime burglary as "burglary in the first degree" and daytime burglary as "burglary in the second degree," under most circumstances (this state now uses building type — residential vs. commercial — in making the 
determination, with residential burglaries carrying the more serious charge). In states that continue to punish nighttime burglary more severely than daytime burglary and the crime occurred during twilight, a standard of 30 minutes after sunset or before sunrise will often be observed as the boundary between night and day.

England and Wales

In England and Wales, burglary is dealt with in the Theft Act 1968 under section 9. Subsection (1)(a) says that any person who enters any building, part of a building, inhabited vehicle or vessel with the intent to steal, cause grievous bodily harm, criminally damage or commit rape will be guilty of the offence of burglary. Subsection (1) (b) provides for a different type of burglary, where any person having entered any building, part of a building, inhabited vehicle or vessel commits a theft or inflicts gross bodily harm. It is a necessary component, however, that in either eventuality that the perpetrator must be trespassing at the time of the offence.

There is also an offence of Aggravated Burglary under Section 10 of the Act. A burglary becomes aggravated when a burglar has with him at the time a weapon of offence, imitation firearm, firearm or explosive. (There is no requirement that any of these items are used in the commission of the offence merely that they are in the possession of the burglar at the time). Maximum sentences for Section 9 offences are 10 years for a non-dwelling and 14 years for a dwelling. Section 10 offences carry a maximum of life imprisonment. Burglary is triable either summarily (before a Magistrate) or on indictment in the Crown Court.

Canada

In Canada, burglary is labeled as "Breaking and Entering" under section 348 of the Criminal Code and is a hybrid offence. The provision of Breaking and Entering consists of "breaking or entering" into or out of a place and either intends to or actually commits an indictable offence.

TRESPASS

(a) A person commits an offense if he enters or remains on or in property, including an aircraft or other vehicle, of another without effective consent or he enters or remains in a building of another without effective consent and he:

(1) Had notice that the entry was forbidden; or

(2) Received notice to depart but failed to do so.

(b) For purposes of this section:

(1) "Entry" means the intrusion of the entire body.

(2) "Notice" means:

(A) Oral or written communication by the owner or someone with apparent authority to act for the owner;

(B) Fencing or other enclosure obviously designed to exclude intruders or to contain livestock;

(C) A sign or signs posted on the property or at the entrance to the building, reasonably likely to come to the attention of intruders, indicating that entry is forbidden;

(D) The placement of identifying purple paint marks on trees or posts on the property provided that the marks are: (I) vertical lines of not less than eight inches in length and not less than one inch in width; 
(ii) placed so that the bottom of the mark is not less than three feet from the ground or more than five feet from the ground; and (iii) Placed at locations that are readily visible to any person approaching the property and no more than:

(a) 100 feet apart on forest land; or

(b) 1,000 feet apart on land other than forest land; or (E) The visible presence on the property of a crop grown for human consumption that is under cultivation, in the process of being harvested, or marketable if harvested at the time of entry.

(3) "Shelter center" has the meaning assigned by Section 51.002, Human Resources Code.

(4) "Forest land" means land on which the trees are potentially valuable for timber products.

(5) "Agricultural land" has the meaning assigned by Section 75.001, Civil Practice and Remedies Code.

(6) "Superfund site" means a facility that:

(A) Is on the National Priorities List established under Section 105 of the federal Comprehensive Environmental Response, Compensation, and Liability Act of 1980 (42 U.S.C. Section 9605); or

(B) Is listed on the state registry established under Section 361.181, Health and Safety Code.

(7) "Critical infrastructure facility" means one of the following, if completely enclosed by a fence or other physical barrier that is obviously designed to exclude intruders:

(A) A chemical manufacturing facility;

(B) A refinery;

(C) An electrical power generating facility, substation, switching station, electrical control center, or electrical transmission or distribution facility;

(D) A water intake structure, water treatment facility, wastewater treatment plant, or pump station;

(E) A natural gas transmission compressor station;

(F) A liquid natural gas terminal or storage facility;

(G) A telecommunications central switching office;

(H) A port, railroad switching yard, trucking terminal, or other freight transportation facility;

(I) a gas processing plant, including a plant used in the processing, treatment, or fractionation of natural gas; or $(\mathrm{J})$ A transmission facility used by a federally licensed radio or television station.

(c) It is a defense to prosecution under this section that the actor at the time of the offense was a fire fighter or emergency medical services personnel, as that term is defined by Section 773.003, Health and Safety Code, acting in the lawful discharge of an official duty under exigent circumstances.

(d) An offense under Subsection (e) is a Class C misdemeanor unless it is committed in a habitation or unless the actor carries a deadly weapon on or about the actor's person during the commission of the offense, in which event it is a Class a misdemeanor. An offense under Subsection (a) is a Class B misdemeanor, except that the offense is a

Class A misdemeanor if:

(1) The offense is committed: 
(A) In a habitation or a shelter center;

(B) On a Superfund site; or

(C) On or in a critical infrastructure facility; or

(2) The actor carries a deadly weapon on or about his person during the commission of the offense.

(e) A person commits an offense if without express consent or if without authorization provided by any law, whether in writing or other form, the person:

(1) Enters or remains on agricultural land of another;

(2) Is on the agricultural land and within 100 feet of the boundary of the land when apprehended; and

(3) Had notice that the entry was forbidden or received notice to depart but failed to do so.

(f) It is a defense to prosecution under this section that:

(1) The basis on which entry on the property or land or in the building was forbidden is that entry with a handgun was forbidden; and

(2) The person was carrying a concealed handgun and a license issued under Subchapter H, Chapter 411, Government Code, to carry a concealed handgun of the same category the person was carrying. Text of sub sec. (g) as added by Acts 2005, 79th Leg., ch. 1093.

(g) This section does not apply if:

(1) The basis on which entry on the property or land or in the building was forbidden is that entry with a handgun or other weapon was forbidden; and

(2) the actor at the time of the offense was a peace officer, including a commissioned peace officer of a recognized state, or a special investigator under Article 2.122, Code of Criminal Procedure, regardless of whether the peace officer or special investigator was engaged in the actual discharge of an official duty while carrying the weapon.

Text of sub sec. (g) as added by Acts 2005, 79th Leg., ch. 1337. (g) It is a defense to prosecution under this section that the actor entered a railroad switching yard or any part of a railroad switching yard and was at that time an employee or a representative of employees exercising a right under the Railway Labor Act (45 U.S.C. Section 151 et seq.).

Text of sub sec. (h) as added by Acts 2005, 79th Leg., ch. 1093. (h) For purposes of Subsection (g), "recognized state" means another state with which the attorney general of this state, with the approval of the governor of this state, negotiated an agreement after determining that the other state:

(1) Has firearm proficiency requirements for peace officers; and

(2) Fully recognizes the right of peace officers commissioned in this state to carry weapons in the other state. Text of sub sec. (h) as added by Acts 2005, 79th Leg., ch. 1337. (h) At the punishment stage of a trial in which the attorney representing the state seeks the increase in punishment provided by Subsection (d) (1) (C), the defendant may raise the issue as to whether the defendant entered or remained on or in a critical infrastructure facility as part of a peaceful or lawful assembly, including an attempt to exercise rights guaranteed by state or federal labor laws. If the defendant proves the issue in the affirmative by a preponderance of the evidence, the increase in punishment provided by Subsection (d) (1) (C) does not apply.

TRESPASS BY HOLDER OF LICENSE TO CARRY CONCEALED HANDGUN

(a) A license holder commits an offense if the license holder: 
(1) Carries a handgun under the authority of Subchapter H, Chapter 411, Government Code, on property of another without effective consent; and

(2) Received notice that:

(A) Entry on the property by a license holder with a concealed handgun was forbidden; or

(B) Remaining on the property with a concealed handgun was forbidden and failed to depart.

(b) For purposes of this section, a person receives notice if the owner of the property or someone with apparent authority to act for the owner provides notice to the person by oral or written communication.

(c) In this section:

(1) "Entry" has the meaning assigned by Section 30.05(b).

(2) "License holder" has the meaning assigned by Section 46.035(f).

(3) "Written communication" means:

(A) a card or other document on which is written language identical to the following: "Pursuant to Section 30.06, Penal Code (trespass by holder of license to carry a concealed handgun), a person licensed under Subchapter H, Chapter 411, Government Code (concealed handgun law), may not enter this property with a concealed handgun"; or

(B) A sign posted on the property that:

(I) includes the language described by Paragraph (A) in both English and Spanish;

(ii) Appears in contrasting colors with block letters at least one inch in height; and

(iii) Is displayed in a conspicuous manner clearly visible to the public.

(d) An offense under this section is a Class A misdemeanor.

(e) It is an exception to the application of this section that the property on which the license holder carries a handgun is owned or leased by a governmental entity and is not a premises or other place on which the license holder is prohibited from carrying the handgun under Section 46.03 or 46.035 .

Under the Islamic criminal law burglary and trespass have same mean and lawmaker doesn't discrepancy in this terms punishment for this crimes are jail.

Larceny

Larceny is a common law crime involving stealing. Under common law, larceny is the trespasser taking and asportation of the (tangible) personal property of another with the intent to deprive him or her of it permanently.

- Trespass limits the crime to acts which involve a violation of the right of possession--that is, lawful possession prior to the act negates trespass (see embezzlement). Even if the prior owner did not have possession (as in, lost or misplaced), then he is deemed to still have constructive possession. Therefore, if a finder knew or could determine who the owner was, and at the time he found it intended to keep it, then the finder has committed trespass. Generally, however, the law cannot convict a finder unless the property bore some indication it belonged to somebody, and the finder intended to keep it at the time of the finding. (Model Penal Code sec. 223.5)

- $\quad$ Asportation and taking involve physical movement of the property. That is, if the property is not moved, then there is no larceny. Furthermore, if a person (T) tells 
the other (I) that the item is his (T's), and then authorizes me to take it, and I take off with it, it is $\mathrm{T}$ whom the law deems to have asported--because I am protected by the fiction of innocent agency.

Taking is typically defined as exercising control and dominion over the property. Larceny under common law never applied to real property, or services. However, in the U.S., the Model Penal Code (MPC) states that services can be the subject of theft. Wild animals (ferrae naturae) are deemed to not be the property of the owner of whatever land they are found on, so takings of wild animals are also not subject to larceny.

One cannot "steal" one's own property. However, larceny is a crime of possession, not ownership. If a vehicle is under possession of a mechanic, and the owner takes the vehicle, he could be guilty of larceny. (This is also known as the mechanic's lien.)

- Intent requires that one intended to deprive the possessor "permanently" of the property. Although the mens rea of larceny is the intent to steal, the focus is on the loss to the possessor, not the gain to the defendant. Thus, even if the thief did not gain in the taking, if the possessor lost in the process. Courts have also held that permanence can be more than keeping forever. Permanence can include the intent to deprive the possessor of economic significance, even if he plans on returning it later. Unfortunately, the mens rea and actus Reus must coincide. If one rents a car with intent to return, then decides to keep it, then there is no larceny (see embezzlement).

In most of the United States the common law definitions of certain crimes have been modified. Quite often the general crime of theft has replaced larceny, and most related common law and statutory crimes such as embezzlement, false pretenses, robbery, and receipt of stolen property.

- Larceny by Trick or Deception occurs when the victim of larceny is tricked by a misrepresentation of fact into giving up possession of property. This should not be confused with false pretenses, where the victim is tricked into giving up title to the property.

- Grand larceny is typically defined as larceny of a significant amount of property. In the U.S., it is often defined as an amount valued at \$200 or more. Grand larceny is often classified as a felony with the concomitant possibility of a harsher sentence. Because of its distinctive meter, the phrase is often heard in the lyrics of gangster rap compositions.

ROBBERY

\section{Definitions OF PROPERTY}

(1) "In the course of committing theft" means conduct that occurs in an attempt to commit, during the commission or in immediate flight after the attempt or commission of theft.

(2) "Property" means:

(A) Tangible or intangible personal property including anything severed from land; or

(B) A document, including money that represents or embodies

\section{ROBBERY}

(a) A person commits an offense if, in the course of committing theft as defined in Chapter 31 and with intent to obtain or maintain control of the property, he:

(1) Intentionally, knowingly, or recklessly causes bodily injury to another; or 
(2) Intentionally or knowingly threatens or places another in fear of imminent bodily injury or death.

(b) An offense under this section is a felony of the second degree. AGGRAVATED ROBBERY

(a) A person commits an offense if he commits robbery as defined in Section 29.02, and he:

(1) causes serious bodily injury to another;

(2) Uses or exhibits a deadly weapon; or

(3) Causes bodily injury to another person or threatens or places another person in fear of imminent bodily injury or death, if the other person is:

(A) 65 years of age or older; or

(B) A disabled person.

(b) An offense under this section is a felony of the first degree.

(c) In this section, "disabled person" means an individual with a mental, physical, or developmental disability that is substantially unable to protect him from harm.

THEFT

(1) "Deception" means:

(A) creating or confirming by words or conduct a false impression of law or fact that is likely to affect the judgment of another in the transaction, and that the actor does not believe to be true;

(B) failing to correct a false impression of law or fact that is likely to affect the judgment of another in the transaction, that the actor previously created or confirmed by words or conduct, and that the actor does not now believe to be true;

(C) Preventing another from acquiring information likely to affect his judgment in the transaction;

(D) selling or otherwise transferring or encumbering property without disclosing a lien, security interest, adverse claim, or other legal impediment to the enjoyment of the property, whether the lien, security interest, claim, or impediment is or is not valid, or is or is not a matter of official record; or

(E) promising performance that is likely to affect the judgment of another in the transaction and that the actor does not intend to perform or knows will not be performed, except that failure to perform the promise in issue without other evidence of intent or knowledge is not sufficient proof that the actor did not intend to perform or knew the promise would not be performed.

(2) "Deprive" means:

(A) To withhold property from the owner permanently or for so extended a period of time that a major portion of the value or enjoyment of the property is lost to the owner;

(B) To restore property only upon payment of reward or other compensation; or

(C) To dispose of property in a manner that makes recovery of the property by the owner unlikely.

(3) "Effective consent" includes consent by a person legally authorized to act for the owner. Consent is not effective if:

(A) Induced by deception or coercion;

(B) Given by a person the actor knows is not legally authorized to act for the owner; 
(C) Given by a person who by reason of youth, mental disease or defect, or intoxication is known by the actor to be unable to make reasonable property dispositions?

(D) Given solely to detect the commission of an offense; or

(E) Given by a person who by reason of advanced age is known by the actor to have a diminished capacity to make informed and rational decisions about the reasonable disposition of property.

(4) "Appropriate" means:

(A) To bring about a transfer or purported transfer of title to or other non possessor interest in property, whether to the actor or another; or

(B) To acquire or otherwise exercise control over property other than real property.

(5) "Property" means:

(A) Real property;

(B) Tangible or intangible personal property including anything severed from land; or

(C) A document, including money that represents or embodies anything of value.

(6) "Service" includes:

(A) Labor and professional service;

(B) Telecommunication, public utility, or transportation service;

(C) Lodging, restaurant service, and entertainment; and

(D) The supply of a motor vehicle or other property for use.

(7) "Steal" means to acquire property or service by theft.

(8) "Certificate of title" has the meaning assigned by Section 501.002, Transportation Code.

(9) "Used or secondhand motor vehicle" means a used motor vehicle, as that term is defined by Section 501.002, Transportation Code.

(10) "Elderly individual" has the meaning assigned by Section 22.04(c).

CONSOLIDATION OF THEFT OFFENSES Theft as defined in Section 31.03 constitutes a single offense superseding the separate offenses previously known as theft, theft by false pretext, conversion by a bailee, theft from the person, shoplifting, acquisition of property by threat, swindling, swindling by worthless check, embezzlement, extortion, receiving or concealing embezzled property, and receiving or concealing stolen property.

Acts 1973, 63rd Leg., p. 883, ch. 399, Sec. 1, eff. Jan. 1, 1974.

Amended by Acts 1993, 73rd Leg., ch. 900, Sec. 1.01, eff. Sept. 1, 1994.Sec. 31.03. THEFT. (a) A person commits an offense if he unlawfully appropriates property with intent to deprive the owner of property.

(b) Appropriation of property is unlawful if:

(1) It is without the owner's effective consent;

(2) The property is stolen and the actor appropriates the property knowing it was stolen by another; or

(3) Property in the custody of any law enforcement agency was explicitly represented by any law enforcement agent to the actor as being stolen and the actor appropriates the property believing it was stolen by another.

(c) For purposes of Subsection (b): 
(1) evidence that the actor has previously participated in recent transactions other than, but similar to, that which the prosecution is based is admissible for the purpose of showing knowledge or intent and the issues of knowledge or intent are raised by the actor's plea of not guilty;

(2) the testimony of an accomplice shall be corroborated by proof that tends to connect the actor to the crime, but the actor's knowledge or intent may be established by the uncorroborated testimony of the accomplice;

(3) an actor engaged in the business of buying and selling used or secondhand personal property, or lending money on the security of personal property deposited with the actor, is presumed to know

upon receipt by the actor of stolen property (other than a motor vehicle subject to Chapter 501, Transportation Code) that the property has been previously stolen from another if the actor pays for or loans against the property $\$ 25$ or more (or consideration of equivalent value) and the actor knowingly or recklessly:

(A) Fails to record the name, address, and physical description or identification number of the seller or pledgor;

(B) fails to record a complete description of the property, including the serial number, if reasonably available, or other identifying characteristics; or

(C) Fails to obtain a signed warranty from the seller or pledgor that the seller or pledgor has the right to possess the property. It is the express intent of this provision that the presumption arises unless the actor complies with each of the numbered requirements;

(4) for the purposes of Subdivision (3)(A), "identification number" means driver's license number, military identification number, identification certificate, or other official number capable of identifying an individual;

(5) Stolen property does not lose its character as stolen when recovered by any law enforcement agency;

(6) an actor engaged in the business of obtaining abandoned or wrecked motor vehicles or parts of an abandoned or wrecked motor vehicle for resale, disposal, scrap, repair, rebuilding, demolition, or other form of salvage is presumed to know on receipt by the actor of stolen property that the property has been previously stolen from another if the actor knowingly or recklessly:

(A) fails to maintain an accurate and legible inventory of each motor vehicle component part purchased by or delivered to the actor, including the date of purchase or delivery, the name, age, address, sex, and driver's license number of the seller or person making the delivery, the license plate number of the motor vehicle in which the part was delivered, a complete description of the part, and the vehicle identification number of the motor vehicle from which the part was removed, or in lieu of maintaining an inventory, fails to record the name and certificate of inventory number of the person who dismantled the motor vehicle from which the part was obtained;

(B) fails on receipt of a motor vehicle to obtain a certificate of authority, sales receipt, or transfer document as required by Chapter 683, Transportation Code, or a certificate of title showing that the motor vehicle is not subject to a lien or that all recorded liens on the motor vehicle have been released; or 
(C) fails on receipt of a motor vehicle to immediately remove an unexpired license plate from the motor vehicle, to keep the plate in a secure and locked place, or to maintain an inventory, on forms provided by the Texas Department of Transportation, of license plates kept under this paragraph, including for each plate or set of plates the license plate number and the make, motor number, and vehicle identification number of the motor vehicle from which the plate was removed;

(7) An actor who purchases or receives a used or secondhand motor vehicle is presumed to know on receipt by the actor of the motor vehicle that the motor vehicle has been previously stolen from another if the actor knowingly or recklessly:

(A) fails to report to the Texas Department of Transportation the failure of the person who sold or delivered the motor vehicle to the actor to deliver to the actor a properly executed certificate of title to the motor vehicle at the time the motor vehicle was delivered; or

(B) fails to file with the county tax assessor-collector of the county in which the actor received the motor vehicle, not later than the 20th day after the date the actor received the motor vehicle, the registration license receipt and certificate of title or evidence of title delivered to the actor in accordance with Subchapter D, Chapter 520, Transportation Code, at the time the motor vehicle was delivered;

(8) an actor who purchases or receives from any source other than a licensed retailer or distributor of pesticides a restricted-use pesticide or a state-limited-use pesticide or a compound, mixture, or preparation containing a restricted-use or statelimited-use pesticide is presumed to know on receipt by the actor of the pesticide or compound, mixture, or preparation that the pesticide or compound, mixture, or preparation has been previously stolen from another if the actor:

(A) Fails to record the name, address, and physical description of the seller or pledgor;

(B) fails to record a complete description of the amount and type of pesticide or compound, mixture, or preparation purchased or received; and

(C) Fails to obtain a signed warranty from the seller or pledgor that the seller or pledgor has the right to possess the property; and

(9) an actor who is subject to Section 409, Packers and Stockyards

Act (7 U.S.C. Section 228b), that obtains livestock from a commission merchant by representing that the actor will make prompt payment is presumed to have induced the commission merchant's consent by deception if the actor fails to make full payment in accordance with Section 409, Packers and Stockyards Act (7 U.S.C. Section 228b).

(d) It is not a defense to prosecution under this section that:

(1) The offense occurred as a result of a deception or strategy on the part of a law enforcement agency, including the use of an undercover operative or peace officer;

(2) The actor was provided by a law enforcement agency with a facility in which to commit the offense or an opportunity to engage in conduct constituting the offense; or

(3) the actor was solicited to commit the offense by a peace officer, and the solicitation was of a type that would encourage a person predisposed to commit the offense to actually commit the offense, but would not encourage a person not predisposed to commit the offense to actually commit the offense.

(e) Except as provided by Subsection (f), an offense under this section is:

(1) A Class C misdemeanor if the value of the property stolen is less than: (A) $\$ 50$; or

(B) \$20 and the defendant obtained the property by issuing or passing a check or similar sight order in a manner described by Section 31.06; 
(2) A Class B misdemeanor if:

(A) The value of the property stolen is:

(I) $\$ 50$ or more but less than $\$ 500$; or

(ii) $\$ 20$ or more but less than $\$ 500$ and the defendant obtained the property by issuing or passing a check or similar sight order in a manner described by Section 31.06; or

(B) The value of the property stolen is less than:

(I) $\$ 50$ and the defendant has previously been convicted of any grade of theft; or

(ii) $\$ 20$, the defendant has previously been convicted of any grade of theft, and the defendant obtained the property by issuing or passing a check or similar sight order in a manner described by Section 31.06;

(3) A Class A misdemeanor if the value of the property stolen is $\$ 500$ or more but less than $\$ 1,500$;

(4) A state jail felony if:

(A) the value of the property stolen is $\$ 1,500$ or more but less than $\$ 20,000$, or the property is less than 10 head of cattle, horses, or exotic livestock or exotic fowl as defined by Section 142.001, Agriculture Code, or any part thereof under the value of $\$ 20,000$, or less than 100 head of sheep, swine, or goats or any part thereof under the value of $\$ 20,000$;

(B) Regardless of value, the property is stolen from the person of another or from a human corpse or grave;

(C) The property stolen is a firearm, as defined by Section 46.01;

(D) The value of the property stolen is less than $\$ 1,500$ and the defendant has been previously convicted two or more times of any grade of theft; or

(E) The property stolen is an official ballot or official carrier envelope for an election;

(5) A felony of the third degree if the value of the property stolen is $\$ 20,000$ or more but less than $\$ 100,000$, or the property is:

(A) 10 or more head of cattle, horses, or exotic livestock or exotic fowl as defined by Section 142.001, Agriculture Code, stolen during a single transaction and having an aggregate value of less than $\$ 100,000$; or

(B) 100 or more head of sheep, swine, or goats stolen during a single transaction and having an aggregate value of less than $\$ 100,000$;

(6) A felony of the second degree if the value of the property stolen is $\$ 100,000$ or more but less than $\$ 200,000$; or

(7) A felony of the first degree if the value of the property stolen is $\$ 200,000$ or more.

(f) An offense described for purposes of punishment by Subsections

(e) (1)-(6) is increased to the next higher category of offense if it is shown on the trial of the offense that:

(1) the actor was a public servant at the time of the offense and the property appropriated came into the actor's custody, possession, or control by virtue of his status as a public servant;

(2) the actor was in a contractual relationship with government at the time of the offense and the property appropriated came into the actor's custody, possession, or control by virtue of the contractual relationship; or

(3) The owner of the property appropriated was at the time of the offense an elderly individual.

(g) For the purposes of Subsection (a), a person is the owner of exotic livestock or exotic fowl as defined by Section 142.001, Agriculture 
Code, only if the person qualifies to claim the animal under Section 142.0021, Agriculture Code, if the animal is an estray.

(h) In this section:

(1) "Restricted-use pesticide" means a pesticide classified as a restricted-use pesticide by the administrator of the Environmental Protection Agency under 7 U.S.C. Section 136a, as that law existed on January 1, 1995, and containing an active ingredient listed in the federal regulations adopted under that law (40 C.F.R. Section 152.175) and in effect on that date.

(2) "State-limited-use pesticide" means a pesticide classified as a state-limited-use pesticide by the Department of Agriculture under Section 76.003, Agriculture Code, as that section existed on January 1, 1995, and containing an active ingredient listed in the rules adopted under that section (4 TAC Section 7.24) as that section existed on that date.

(I) For purposes of Subsection (c)(9), "livestock" and "commission merchant" have the meanings assigned by Section 147.001, Agriculture Code.

(j) With the consent of the appropriate local county or district attorney, the attorney general has concurrent jurisdiction with that consenting local prosecutor to prosecute an offense under this section that involves the state Medicaid program. THEFT OF SERVICE

(a) A person commits theft of service if, with intent to avoid payment for service that he knows is provided only for compensation:

(1) $\mathrm{He}$ intentionally or knowingly secures performance of the service by deception, threat, or false token;

(2) having control over the disposition of services of another to which he is not entitled, he intentionally or knowingly diverts the other's services to his own benefit or to the benefit of another not entitled to them;

(3) having control of personal property under a written rental agreement, he holds the property beyond the expiration of the rental period without the effective consent of the owner of the property, thereby depriving the owner of the property of its use in further rentals; or

(4) He intentionally or knowingly secures the performance of the service by agreeing to provide compensation and, after the service is rendered, fails to make payment after receiving notice demanding payment.

(b) For purposes of this section, intent to avoid payment is presumed

if:

(1) the actor absconded without paying for the service or expressly refused to pay for the service in circumstances where payment is ordinarily made immediately upon rendering of the service, as in hotels, campgrounds, recreational vehicle parks, restaurants, and comparable establishments;

(2) The actor failed to make payment under a service agreement within 10 days after receiving notice demanding payment;

(3) the actor returns property held under a rental agreement after the expiration of the rental agreement and fails to pay the applicable rental charge for the property within 10 days after the date on which the actor received notice demanding payment; or

(4) The actor failed to return the property held under a rental agreement: 
(A) within five days after receiving notice demanding return, if the property is valued at less than $\$ 1,500$; or

(B) Within three days after receiving notice demanding return, if the property is valued at $\$ 1,500$ or more.

(c) For purposes of Subsections (a)(4), (b)(2), and (b)(4), notice shall be notice in writing, sent by registered or certified mail with return receipt requested or by telegram with report of delivery requested, and addressed to the actor at his address shown on the rental agreement or service agreement.

(d) If written notice is given in accordance with Subsection (c), it is presumed that the notice was received no later than five days after it was sent.

(e) An offense under this section is:

(1) A Class C misdemeanor if the value of the service stolen is less than $\$ 20$;

(2) A Class B misdemeanor if the value of the service stolen is $\$ 20$ or more but less than $\$ 500$;

(3) A Class A misdemeanor if the value of the service stolen is $\$ 500$ or more but less than $\$ 1,500$;

(4) A state jail felony if the value of the service stolen is $\$ 1,500$ or more but less than $\$ 20,000$;

(5) A felony of the third degree if the value of the service stolen is $\$ 20,000$ or more but less than $\$ 100,000$;

(6) A felony of the second degree if the value of the service stolen is $\$ 100,000$ or more but less than $\$ 200,000$; or

(7) A felony of the first degree if the value of the service stolen is $\$ 200,000$ or more.

(f) Notwithstanding any other provision of this code, any police or other report of stolen vehicles by a political subdivision of this state shall include on the report any rental vehicles whose renters have been shown to such reporting agency to be in violation of Subsection

(b) (2) and shall indicate that the renting agency has complied with the notice requirements demanding return as provided in this section.

(g) It is a defense to prosecution under this section that:

(1) The defendant secured the performance of the service by giving a post-dated check or similar sight order to the person performing the service; and

(2) The person performing the service or any other person presented the check or sight order for payment before the date on the check or sight order. THEFT OF TRADE SECRETS

(a) For purposes of this section:

(1) "Article" means any object, material, device, or substance or any copy thereof, including a writing, recording, drawing, sample, specimen, prototype, model, photograph, microorganism, blueprint, or map.

(2) "Copy" means a facsimile, replica, photograph, or other reproduction of an article or a note, drawing, or sketch made of or from an article.

(3) "Representing" means describing, depicting, containing, constituting, reflecting, or recording.

(4) "Trade secret" means the whole or any part of any scientific or technical information, design, process, procedure, formula, or improvement that has value and 
that the owner has taken measures to prevent from becoming available to persons other than those selected by the owner to have access for limited purposes.

(b) A person commits an offense if, without the owner's effective consent, he knowingly:

(1) steals a trade secret;

(2) Makes a copy of an article representing a trade secret; or

(3) Communicates or transmits a trade secret.

(c) An offense under this section is a felony of the third degree.

Acts 1973, 63rd Leg., p. 883, ch. 399, Sec. 1, eff. Jan. 1, 1974.

Amended by Acts 1993, 73rd Leg., ch. 900, Sec. 1.01, eff. Sept. 1, 1994.

PRESUMPTION FOR THEFT BY CHECK

(a) If the actor obtained property or secured performance of service by issuing or passing a check or similar sight order for the payment of money, when the issuer did not have sufficient funds in or on deposit with the bank or other drawee for the payment in full of the

check or order as well as all other checks or orders then outstanding, it is prima facie evidence of his intent to deprive the owner of property under Section 31.03 (Theft) including a drawee or third-party holder in due course who negotiated the check or to avoid payment for service under Section 31.04 (Theft of Service) (except in the case of a postdated check or order) if:

(1) He had no account with the bank or other drawee at the time he issued the check or order; or

(2) Payment was refused by the bank or other drawee for lack of funds or insufficient funds, on presentation within 30 days after issue, and the issuer failed to pay the holder in full within 10 days after receiving notice of that refusal.

(b) For purposes of Subsection (a) (2) or (f) (3), notice may be actual notice or notice in writing that:

(1) Is sent by registered or certified mail with return receipt requested or by telegram with report of delivery requested;

(2) Is addressed to the issuer at his address shown on:

(A) The check or order;

(B) The records of the bank or other drawee; or

(C) The records of the person to whom the check or order has been issued or passed; and

(3) Contains the following statement:

"This is a demand for payment in full for a check or order not paid because of a lack of funds or insufficient funds. If you fail to make payment in full within 10 days after the date of receipt of this notice, the failure to pay creates a presumption for committing an offense, and this matter may be referred for criminal prosecution."

(c) If written notice is given in accordance with Subsection (b), it is presumed that the notice was received no later than five days after it was sent.

(d) Nothing in this section prevents the prosecution from establishing the requisite intent by direct evidence.

(e) Partial restitution does not preclude the presumption of the requisite intent under this section.

(f) If the actor obtained property by issuing or passing a check or similar sight order for the payment of money, the actor's intent to deprive the owner of the property 
under Section 31.03 (Theft) is presumed, except in the case of a postdated check or order, if:

(1) The actor ordered the bank or other drawee to stop payment on the check or order;

(2) The bank or drawee refused payment to the holder on presentation of the check or order within 30 days after issue;

(3) The owner gave the actor notice of the refusal of payment and made a demand to the actor for payment or return of the property; and

(4) The actor failed to:

(A) Pay the holder within 10 days after receiving the demand for payment; or

(B) Return the property to the owner within 10 days after receiving the demand for return of the property. UNAUTHORIZED USE OF A VEHICLE

(a) A person commits an offense if he intentionally or knowingly operates another's boat, airplane, or motor-propelled vehicle without the effective consent of the owner.

(b) An offense under this section is a state jail felony.

Acts 1973, 63rd Leg., p. 883, ch. 399, Sec. 1, eff. Jan. 1, 1974.

Amended by Acts 1993, 73rd Leg., ch. 900, Sec. 1.01, eff. Sept. 1, 1994.

Sec. 31.08. VALUE. (a) Subject to the additional criteria of Subsections (b) and (c), value under this chapter is: (1) The fair market value of the property or service at the time and place of the offense; or

(2) If the fair market value of the property cannot be ascertained, the cost of replacing the property within a reasonable time after the theft.

(b) The value of documents, other than those having a readily ascertainable market value, is:

(1) The amount due and collectible at maturity less that part which has been satisfied, if the document constitutes evidence of a debt; or

(2) The greatest amount of economic loss that the owner might reasonably suffer by virtue of loss of the document, if the document is other than evidence of a debt.

(c) If property or service has value that cannot be reasonably ascertained by the criteria set forth in Subsections (a) and (b), the property or service is deemed to have a value of $\$ 500$ or more but less than $\$ 1,500$.

(d) If the actor proves by a preponderance of the evidence that he gave consideration for or had a legal interest in the property or service stolen, the amount of the consideration or the value of the interest so proven shall be deducted from the value of the property or service ascertained under Subsection (a), (b), or (c) to determine value for purposes of this chapter. AGGREGATION OF AMOUNTS INVOLVED IN THEFT

When amounts are obtained in violation of this chapter pursuant to one scheme or continuing course of conduct, whether from the same or several sources, the conduct may be considered as one offense and the amounts aggregated in determining the grade of the offense. Acts 1973, 63rd Leg., p. 883, ch. 399, Sec. 1, eff. Jan. 1, 1974. 
Amended by Acts 1993, 73rd Leg., ch. 900, Sec. 1.01, eff. Sept. 1, 1994. ACTOR'S INTEREST IN PROPERTY

It is no defense to prosecution under this chapter that the actor has an interest in the property or service stolen if another person has the right of exclusive possession of the property.

Acts 1973, 63rd Leg., p. 883, ch. 399, Sec. 1, eff. Jan. 1, 1974.

Amended by Acts 1993, 73rd Leg., ch. 900, Sec. 1.01, eff. Sept. 1, 1994.

TAMPERING WITH IDENTIFICATION NUMBERS

(a) A person commits an offense if the person:

(1) knowingly or intentionally removes, alters, or obliterates the serial number or other permanent identification marking on tangible personal property; or

(2) Possesses, sells, or offers for sale tangible personal property and: (A) the actor knows that the serial number or other permanent identification marking has been removed, altered, or obliterated; or

(B) A reasonable person in the position of the actor would have known that the serial number or other permanent identification marking has been removed, altered, or obliterated.

(b) It is an affirmative defense to prosecution under this section that the person was:

(1) The owner or acting with the effective consent of the owner of the property involved;

(2) A peace officer acting in the actual discharge of official duties; or

(3) Acting with respect to a number assigned to a vehicle by the Texas Department of Transportation and the person was:

(A) In the actual discharge of official duties as an employee or agent of the department; or

(B) In full compliance with the rules of the department as an applicant for an assigned number approved by the department.

(c) Property involved in a violation of this section may be treated as stolen for purposes of custody and disposition of the property.

(d) An offense under this section is a Class A misdemeanor.

(e) In this section, "vehicle" has the meaning given by Section 541.201, Transportation Code.

THEFT OF OR TAMPERING WITH MULTICHANNEL VIDEO OR INFORMATION SERVICES

(a) A person commits an offense if, without the authorization of the multi channel video or information services provider, the person intentionally or knowingly:

(1) Makes or maintains a connection, whether physically, electrically, electronically, or inductively, to:

(A) A cable, wire, or other component of or media attached to a multi channel video or information services system; or

(B) A television set, videotape recorder, or other receiver attached to a multi channel video or information system;

(2) Attaches, causes to be attached, or maintains the attachment of a device to:

(A) A cable, wire, or other component of or media attached to a multi channel video or information services system; or 
(B) A television set, videotape recorder, or other receiver attached to a multi channel video or information services system;

(3) Tampers with, modifies, or maintains a modification to a device installed by a multi channel video or information services provider; or

(4) Tampers with, modifies, or maintains a modification to an access device or uses that access device or any unauthorized access device to obtain services from a multi channel video or information services provider.

(b) In this section:

(1) "Access device," "connection," and "device" mean an access device, connection, or device wholly or partly designed to make intelligible an encrypted, encoded, scrambled, or other nonstandard signal carried by a multi channel video or information services provider.

(2) "Encrypted, encoded, scrambled, or other nonstandard signal" means any type of signal or transmission not intended to produce an intelligible program or service without the use of a device, signal, or information provided by a multi channel video or information services provider.

(3) "Multi channel video or information services provider" means a licensed cable television system, video dial tone system, multi channel multipoint distribution services system, direct broadcast satellite system, or other system providing video or information services that are distributed by cable, wire, radio frequency, or other media.

(c) This section does not prohibit the manufacture, distribution, sale, or use of satellite receiving antennas that are otherwise permitted by state or federal law.

(d) An offense under this section is a Class C misdemeanor unless it is shown on the trial of the offense that the actor:

(1) has been previously convicted one time of an offense under this section, in which event the offense is a Class B misdemeanor, or convicted two or more times of an offense under this section, in which event the offense is a Class A misdemeanor; or

(2) committed the offense for remuneration, in which event the offense is a Class A misdemeanor, unless it is also shown on the trial of the offense that the actor has been previously convicted two or more times of an offense under this section, in which event the offense is a Class A misdemeanor with a minimum fine of $\$ 2,000$ and a minimum term of confinement of 180 days.

(e) For the purposes of this section, each connection, attachment, modification, or act of tampering is a separate offense.

Added by Acts 1995, 74th Leg., ch. 318, Sec. 10, eff. Sept. 1, 1995.

Amended by Acts 1999, 76th Leg., ch. 858, Sec. 1, eff. Sept. 1, 1999.

MANUFACTURE, DISTRIBUTION, OR ADVERTISEMENT

OF MULTICHANNEL VIDEO OR INFORMATION

SERVICES DEVICE

(a) A person commits an offense if the person for remuneration intentionally or knowingly manufactures, assembles, modifies,

imports into the state, exports out of the state, distributes, advertises, or offers for sale, with an intent to aid in the commission of an offense under Section 31.12, a device, a kit or part for a device, or a plan for a system of components wholly or partly designed to make intelligible an encrypted, encoded, scrambled, or other nonstandard signal carried or caused by a multi channel video or information services provider. 
(b) In this section, "device," "encrypted, encoded, scrambled, or other nonstandard signal," and "multi channel video or information services provider" have the meanings assigned by Section 31.12.

(c) This section does not prohibit the manufacture, distribution, advertisement, offer for sale, or use of satellite receiving antennas that are otherwise permitted by state or federal law.

(d) An offense under this section is a Class A misdemeanor. Added by Acts 1995, 74th Leg., ch. 318, Sec. 10, eff. Sept. 1, 1995. Amended by Acts 1999, 76th Leg., ch. 858, Sec. 2, eff. Sept. 1, 1999. SALE OR LEASE OF MULTICHANNEL VIDEO OR INFORMATION SERVICES DEVICE

(a) A person commits an offense if the person intentionally or knowingly sells or leases, with an intent to aid in the commission of an offense under Section 31.12, a device, a kit or part for a device, or a plan for a system of components wholly or partly designed to make intelligible an encrypted, encoded, scrambled, or other nonstandard signal carried or caused by a multi channel video or information services provider.

(b) In this section, "device," "encrypted, encoded, scrambled, or other nonstandard signal," and "multi channel video or information services provider" have the meanings assigned by Section 31.12.

(c) This section does not prohibit the sale or lease of satellite receiving antennas that are otherwise permitted by state or federal law without providing notice to the comptroller.

(d) An offense under this section is a Class A misdemeanor. Added by Acts 1999, 76th Leg., ch. 858, Sec. 3, eff. Sept. 1, 1999 POSSESSION, MANUFACTURE, OR DISTRIBUTION OF

\section{CERTAIN INSTRUMENTS USED TO COMMIT RETAIL}

THEFT

(a) In this section:

(1) "Retail theft detector" means an electrical, mechanical, electronic, or magnetic device used to prevent or detect shoplifting and includes any article or component part essential to the proper operation of the device.

(2) "Shielding or deactivation instrument" means any item or tool designed, made, or adapted for the purpose of preventing the detection of stolen merchandise by a retail theft detector. The term includes a metal-lined or foil-lined shopping bag and any item used to remove a security tag affixed to retail merchandise.

(b) A person commits an offense if, with the intent to use the instrument to commit theft, the person:

(1) Possesses a shielding or deactivation instrument; or

(2) Knowingly manufactures, sells, offers for sale, or otherwise distributes a shielding or deactivation instrument.

(c) An offense under this section is a Class A misdemeanor.

Added by Acts 2001, 77th Leg., ch. 109, Sec. 1, eff. Sept. 1, 2001.

STEALING OR RECEIVING STOLEN CHECK OR SIMILAR SIGHT ORDER

(a) A person commits an offense if the person steals an unsigned check or similar sight order or, with knowledge that an unsigned check or similar sight order has been stolen, receives the check or sight order with intent to use it, to sell it, or to transfer it to a person other than the person from whom the check or sight order was stolen.

(b) An offense under this section is a Class A misdemeanor. Added by Acts 1999, 76th Leg., ch. 1413, Sec. 1, eff. Sept. 1, 1999. 
Under the Islamic criminal law larceny divided into precinct witch that's punishment is amputate of hand and punishment of other larceny witch don't have terms of this kind of larceny is jail in Islamic criminal law statement 16 terms for precinct larceny .

Arson

Arson is the crime of setting a fire with intent to cause damage. The common law definition of arson originally contained four elements; the crime required the malicious act of burning the dwelling of another person. Although arson fires are referred to as incendiary, not all incendiary fires are considered arson, the difference being malicious intent.

The first element, "malice," required that the person responsible for the burning must have intended the structure to be damaged by fire, or must have known that there was an obvious risk that the structure would be damaged and shown reckless disregard for this risk. This element of the common law has been changed by statutes in many jurisdictions. Willful or negligent misconduct resulting in a forest fire, e.g., tossing a spent match or cigarette out of a vehicle in a closed area, are also subjects to prosecution under many arson statutes.

The second element, "burning," required that the fire cause actual damage to the property. Under the quaint language of the common law courts "scorching" of the surface was not enough; the property had to at least suffer "charring," meaning that there had to be some damage to the fiber of the wood or other such material from which the dwelling was constructed.

The third element was that the structure had to be a "dwelling" - a place where another person regularly slept (even if the structure was also used as a business, or was temporarily abandoned at the time). This requirement has also been largely abandoned under modern statutes. Where the common law limited arson to setting fire to dwellings, statutes have expanded the crime to include the burning of other structures, such as bridges, vehicles, and private property.

A car after it was set on fire. Under the common law, this would not be arson; but modern arson statutes would cover this.

The fourth element required that the dwelling be the property of another. Because the common law developed long before the advent of fire insurance, it was inconceivable that a person would burn their own dwelling, and a person could not be held accountable for such an act. A separate common law crime called "house burning" could be used to deal with a person who burned their own house if that act created a danger to the homes of others. Under modern arson statutes, however, setting fire to one's own property to defraud an insurance company is also a form of arson. In some jurisdictions, setting fire to mortgaged property without the consent of both the owner and the mortgagee is punishable as arson.

Very often statutes distinguish several degrees of arson. For example arson committed at night is usually deemed as being more serious than that committed during daytime. These statutes may also address the use of Petrol Bombs or accelerants, which can cause more severe and widespread destruction with little effort.

MONEY LAUNDERING

Definitions

(a) A person commits an offense if the person knowingly:

(1) Acquires or maintains an interest in, conceals, possesses, transfers, or transports the proceeds of criminal activity;

(2) Conducts, supervises, or facilitates a transaction involving the proceeds of criminal activity; 
(3) invests, expends, or receives, or offers to invest, expend, or receive, the proceeds of criminal activity or funds that the person believes are the proceeds of criminal activity; or

(4) Finances or invests or intends to finance or invest funds that the person believes are intended to further the commission of criminal activity.

(A-1) Knowledge of the specific nature of the criminal activity giving rise to the proceeds is not required to establish a culpable mental state under this section.

(b) For purposes of this section, a person is presumed to believe that funds are the proceeds of or are intended to further the commission of criminal activity if a peace officer or a person acting at the direction of a peace officer represents to the person that the funds are proceeds of or are intended to further the commission of criminal activity, as applicable, regardless of whether the peace officer or person acting at the peace officer's direction discloses the person's status as a peace officer or that the person is acting at the direction of a peace officer.

(c) It is a defense to prosecution under this section that the person acted with intent to facilitate the lawful seizure, forfeiture, or disposition of funds or other legitimate law enforcement purpose pursuant to the laws of this state or the United States.

(d) It is a defense to prosecution under this section that the transaction was necessary to preserve a person's right to representation as guaranteed by the Sixth Amendment of the United States Constitution and by Article 1, Section 10, of the Texas Constitution or that the funds were received as bona fide legal fees by a licensed attorney and at the time of their receipt, the attorney did not have actual knowledge that the funds were derived from criminal activity.

(e) An offense under this section is: (1) A state jail felony if the value of the funds is $\$ 1,500$ or more but less than $\$ 20,000$;

(2) A felony of the third degree if the value of the funds is $\$ 20,000$ or more but less than $\$ 100,000$;

(3) A felony of the second degree if the value of the funds is $\$ 100,000$ or more but less than $\$ 200,000$; or

(4) A felony of the first degree if the value of the funds is $\$ 200,000$ or more.

(f) For purposes of this section, if proceeds of criminal activity are related to one scheme or continuing course of conduct, whether from the same or several sources, the conduct may be considered as one offense and the value of the proceeds aggregated in determining the classification of the offense.

(g) For purposes of this section, funds on deposit at a branch of a financial institution are considered the property of that branch and any other branch of the financial institution. (h) If conduct that constitutes an offense under this section also constitutes an offense under any other law, the actor may be prosecuted under this section, the other law, or both. PROTECTION FROM CIVIL LIABILITY

Notwithstanding Section 1.03(c), a financial institution or an agent of the financial institution acting in a manner described by Section 34.02(c) is not liable for civil damages to a person who:

(1) Claims an ownership interest in funds involved in an offense under Section 34.02; or

(2) Conducts with the financial institution or an insurer, as defined by Article 1.02, Insurance Code, and a transaction concerning funds involved in an offense 
under Section 34.02. Added by Acts 2005, 79th Leg., ch. 1162, Sec. 3, eff. Sept. 1, 2005. Sec. 34.03.

ASSISTANCE BY ATTORNEY GENERAL The attorney general, if requested to do so by a prosecuting attorney, may assist in the prosecution of an offense under this chapter.

Embezzlement

Embezzlement is the fraudulent conversion of property from a property owner. For instance, a clerk or cashier can embezzle money from his employer; a public officer can embezzle funds from the treasury.

Embezzlement differs from larceny in two ways. First, in embezzlement, an actual conversion must occur. Second, the original taking must not be trespasser. That is, the embezzler must have had the right to possess the item, and used that position of trust to convert the property. Embezzlement may range from the very minor, involving a few dollars, to immense, involving millions of dollars and very sophisticated schemes.

Conversion requires that the theft seriously interfere with the property, rather than just relocate it. As in larceny, the measure is not by the gain to the thief, but the loss to the true owner. Embezzlement was statutorily created to deal with situations where theft could occur while the thief himself was innocent of larceny--typically because of the "lawful possession" element. That is, embezzlement fills in the blanks where larceny cannot.

Embezzlement sometimes involves falsification of records in order to conceal the theft. Embezzlers commonly steal relatively small amounts repeatedly over a long period of time, although some embezzlers steal one large sum at one time. Some very successful embezzlement schemes have continued for many years before being detected due to the skill of the embezzler in concealing the nature of the transactions.

One of the most common methods of embezzlement is to under-report income, and pocket the difference. Another method is to create a false vendor account, and to supply false bills to the company being embezzled so that the checks that are cut appear completely legitimate. Yet another method is to create phantom employees, who are then paid with payroll checks.

The latter two methods should be uncovered by routine audits, but often aren't if the audit is not sufficiently in-depth, because the paperwork appears to be in order. The first method is easier to detect if all transactions are by check or other instrument, but if many transactions are in cash, it is much more difficult to identify. Employers have developed a number of strategies to deal with this problem. In fact, cash registers were invented for just this reason.

MISAPPLICATION OF FIDUCIARY PROPERTY OR PROPERTY OF FINANCIAL INSTITUTION

(a) For purposes of this section:

(1) "Fiduciary" includes:

(A) A trustee, guardian, administrator, executor, conservator, and receiver;

(B) An attorney in fact or agent appointed under a durable power of attorney as provided by Chapter XII, Texas Probate Code;

(C) any other person acting in a fiduciary

capacity, but not a commercial bailee unless the commercial bailee is a party in a motor fuel sales agreement with a distributor or supplier, as those terms are defined by Section 153.001, Tax Code; and

(D) An officer, manager, employee, or agent carrying on fiduciary functions on behalf of a fiduciary.

(2) "Misapply" means deal with property contrary to: 
(A) An agreement under which the fiduciary holds the property; or

(B) A law prescribing the custody or disposition of the property.

(b) A person commits an offense if he intentionally, knowingly, or recklessly misapplies property he holds as a fiduciary or property of a financial institution in a manner that involves substantial risk of loss to the owner of the property or to a person for whose benefit the property is held.

(c) An offense under this section is:

(1) A Class $\mathrm{C}$ misdemeanor if the value of the property misapplied is less than $\$ 20$;

(2) A Class B misdemeanor if the value of the property misapplied is $\$ 20$ or more but less than $\$ 500$;

(3) A Class a misdemeanor if the value of the property misapplied is $\$ 500$ or more but less than $\$ 1,500$;

(4) A state jail felony if the value of the property misapplied is $\$ 1,500$ or more but less than $\$ 20,000$;

(5) A felony of the third degree if the value of the property misapplied is $\$ 20,000$ or more but less than $\$ 100,000$;

(6) A felony of the second degree if the value of the property misapplied is $\$ 100,000$ or more but less than $\$ 200,000$; or

(7) A felony of the first degree if the value of the property misapplied is $\$ 200,000$ or more.

(d) An offense described for purposes of punishment by Subsections (c)(1)-(6) is increased to the next higher category of offense if it is shown on the trial of the offense that the offense was committed against an elderly individual as defined by Section 22.04 .

(e) With the consent of the appropriate local county or district attorney, the attorney general has concurrent jurisdiction with that consenting local prosecutor to prosecute an offense under this section that involves the state Medicaid program.

Under the Islamic criminal law embezzlement include two crimes UN trusteeship and defalcation and deal of their punishment are different, UN trusteeship implement in individual property and defalcation implement in government property.

ISSUANCE OF BAD CHECK

(a) A person commits an offense if he issues or passes a check or similar sight order for the payment of money knowing that the issuer does not have sufficient funds in or on deposit with the bank or other drawee for the payment in full of the check or order as well as all other checks or orders outstanding at the time of issuance.

(b) This section does not prevent the prosecution from establishing the required knowledge by direct evidence; however, for purposes of this section, the issuer's knowledge of insufficient funds is presumed (except in the case of a postdated check or order) if:

(1) He had no account with the bank or other drawee at the time he issued the check or order; or

(2) Payment was refused by the bank or other drawee for lack of funds or insufficient funds on presentation within 30 days after issue and the issuer failed to pay the holder in full within 10 days after receiving notice of that refusal. 
(c) Notice for purposes of Subsection (b) (2) may be actual notice or notice in writing that:

(1) is sent by registered or certified mail with return receipt requested, by telegram with report of delivery requested, or by first class mail if the letter was returned unopened with markings indicating that the address is incorrect and that there is no current forwarding order;

(2) Is addressed to the issuer at his address shown on:

(A) The check or order;

(B) The records of the bank or other drawee; or

(C) The records of the person to whom the check or order has been issued or passed; and

(3) Contains the following statement:

"This is a demand for payment in full for a check or order not paid because of a lack of funds or insufficient funds. If you fail to make payment in full within 10 days after the date of receipt of this notice, the failure to pay creates a presumption for committing an offense, and this matter may be referred for criminal prosecution."

(d) If notice is given in accordance with Subsection (c), it is presumed that the notice was received no later than five days after it was sent.

(e) A person charged with an offense under this section may make restitution for the bad checks. Restitution shall be made through the prosecutor's office if collection and processing were initiated through that office. In other cases restitution may, with the approval of the court in which the offense is filed, be made through the court.

(f) Except as otherwise provided by this subsection, an offense under this section is a Class $\mathrm{C}$ misdemeanor. If the check or similar sight order that was issued or passed was for a child support payment the obligation for which is established under a court order, the offense is a Class B misdemeanor.

(g) An offense under this section is not a lesser included offense of an offense under Section 31.03 or 31.04 .

This one under the Islamic criminal law has prison as punishment and deal of prison depend on sum of check.

False pretenses

False pretenses or obtaining property by false pretenses is a common law crime; it is also a statutorily created law to handle situations where larceny did not work. It consists of (1) obtaining title (2) to personal property of another (3) by an intentional false statement of past or existing fact (4) with intent to defraud the other.

Under common law, false pretense is defined as a representation of a present or past fact, which the thief knows to be false, and which he intends will and does cause the victim to pass title of his property. That is, false pretense is the acquisition of title from a victim by fraud or misrepresentation of a material past or present fact.

Note that it is essential that the victim of the false pretenses must actually be deceived by the misrepresentation, and the fact that the victim is deceived must be a major (if not the only) factor of the victim granting title to the defendant. Simply making a false promise or statement is not sufficient.

The misrepresentation has to be affirmative. A failure to disclose a fact does not fit this misrepresentation in common law, unless there is a fiduciary duty between the thief and victim. Courts have also held that the representation be of a present or past fact. The policy here is that to rely on a future fact is more foolish. People who 
deceive using present facts are more dangerous than those who deceive by false promises. At trial, the prosecution must show not only that the misrepresentation was false, but that the thief knew of the falsity. Additionally, the thief must intend to defraud. Moreover, opinion and puffing are not considered misrepresentation as they color the facts but do not misrepresent them.

Additionally, title must pass between parties. So, deceiving a third party to pass property for a specific purpose, courts have held that this is larceny by trick in that larceny by trick simply uses a deception to deprive the owner of possession, not title.

FRAUD

Definitions

(1) "Financial institution" means a bank, trust company, insurance company, credit union, building and loan association, savings and loan association, investment trust, investment company, or any other organization held out to the public as a place for deposit of funds or medium of savings or collective investment. "Property" means: (A) Real property;

(B) Tangible or intangible personal property including anything severed from land; or

(C) A document, including money that represents or embodies anything of value.

(3) "Service" includes:

(A) Labor and professional service;

(B) Telecommunication, public utility, and transportation service;

(C) Lodging, restaurant service, and entertainment; and

(D) The supply of a motor vehicle or other property for use.

(4) "Steal" means to acquire property or service by theft. VALUE

(a) Subject to the additional criteria of Subsections (b) and (c), value under this chapter is:

(1) The fair market value of the property or service at the time and place of the offense; or

(2) If the fair market value of the property cannot be ascertained, the cost of replacing the property within a reasonable time after the offense.

(b) The value of documents, other than those having a readily ascertainable market value, is:

(1) The amount due and collectible at maturity less any part that has been satisfied, if the document constitutes evidence of a debt; or

(2) The greatest amount of economic loss that the owner might reasonably suffer by virtue of loss of the document, if the document is other than evidence of a debt.

(c) If property or service has value that cannot be reasonably ascertained by the criteria set forth in Subsections (a) and (b), the property or service is deemed to have a value of $\$ 500$ or more but less than $\$ 1,500$.

(d) If the actor proves by a preponderance of the evidence that he gave consideration for or had a legal interest in the property or service stolen, the amount of the consideration or the value of the interest so proven shall be deducted from the value of the property or service ascertained under Subsection (a), (b), or (c) to determine value for purposes of this chapter. AGGREGATION OF AMOUNTS INVOLVED IN FRAUD 
When amounts are obtained in violation of this chapter pursuant to one scheme or continuing course of conduct, whether from the same or several sources, the conduct may be considered as one offense and the amounts aggregated in determining the grade of offense.

FALSE STATEMENT TO OBTAIN PROPERTY OR

CREDIT

(a) For purposes of this section, "credit" includes:

(1) A loan of money;

(2) Furnishing property or service on credit;

(3) Extending the due date of an obligation;

(4) Comaking, endorsing, or guaranteeing a note or other instrument for obtaining credit;

(5) A line or letter of credit; and

(6) A credit card, as defined in Section 32.31 (Credit Card or Debit Card Abuse).

(b) A person commits an offense if he intentionally or knowingly makes a materially false or misleading written statement to obtain property or credit for himself or another.

(c) An offense under this section is: (1) A Class C misdemeanor if the value of the property or the amount of credit is less than $\$ 50$;

(2) A Class B misdemeanor if the value of the property or the amount of credit is $\$ 50$ or more but less than $\$ 500$;

(3) A Class A misdemeanor if the value of the property or the amount of credit is $\$ 500$ or more but less than $\$ 1,500$;

(4) A state jail felony if the value of the property or the amount of credit is $\$ 1,500$ or more but less than $\$ 20,000$;

(5) A felony of the third degree if the value of the property or the amount of credit is $\$ 20,000$ or more but less than $\$ 100,000$;

(6) A felony of the second degree if the value of the property or the amount of credit is $\$ 100,000$ or more but less than $\$ 200,000$; or

(7) A felony of the first degree if the value of the property or the amount of credit is \$200,000 or more. FRAUDULENT TRANSFER OF A MOTOR VEHICLE

(a) In this section:

(1) "Lease" means the grant of use and possession of a motor vehicle for consideration, whether or not the grant includes an option to buy the vehicle.

(2) "Motor vehicle" means a device in, on, or by which a person or property is or may be transported or drawn on a highway, except a device used exclusively on stationary rails or tracks.

(3) "Security interest" means an interest in personal property or fixtures that secures payment or performance of an obligation.

(4) "Third party" means a person other than the actor or the owner of the vehicle.

(5) "Transfer" means to transfer possession, whether or not another right is also transferred, by means of a sale, lease, sublease, lease assignment, or other property transfer. (b) A person commits an offense if the person acquires, accepts possession of, or exercises control over the motor vehicle of another under a written or oral agreement to arrange for the transfer of the vehicle to a third party and: 
(1) knowing the vehicle is subject to a security interest, lease, or lien, the person transfers the vehicle to a third party without first obtaining written authorization from the vehicle's secured creditor, lesser, or lien holder;

(2) Intending to defraud or harm the vehicle's owner, the person transfers the vehicle to a third party;

(3) intending to defraud or harm the vehicle's owner, the person disposes of the vehicle in a manner other than by transfer to a third party; or

(4) The person does not disclose the location of the vehicle on the request of the vehicle's owner, secured creditor, lesser, or lien holder.

(c) For the purposes of Subsection (b)(2), the actor is presumed to have intended to defraud or harm the motor vehicle's owner if the actor does not take reasonable steps to determine whether or not the third party is financially able to pay for the vehicle.

(d) It is a defense to prosecution under Subsection (b)(1) that the entire indebtedness secured by or owed under the security interest, lease, or lien is paid or satisfied in full not later than the 30th day after the date that the transfer was made.

(e) It is not a defense to prosecution under Subsection (b) (1) that the motor vehicle's owner has violated a contract creating a security interest, lease, or lien in the motor vehicle.

(f) An offense under Subsection (b) (1), (b) (2), or (b) (3) is: (1) A state jail felony if the value of the motor vehicle is less than $\$ 20,000$; or

(2) A felony of the third degree if the value of the motor vehicle is $\$ 20,000$ or more.

(g) An offense under Subsection (b) (4) is a Class A misdemeanor.

DECEPTIVE BUSINESS PRACTICES

(a) For purposes of this section:

(1) "Adulterated" means varying from the standard of composition or quality prescribed by law or set by established commercial usage.

(2) "Business" includes trade and commerce and advertising, selling, and buying service or property.

(3) "Commodity" means any tangible or intangible personal property.

(4) "Contest" includes sweepstake, puzzle, and game of chance.

(5) "Deceptive sales contest" means a sales contest:

(A) That misrepresents the participant's chance of winning a prize;

(B) that fails to disclose to participants on a conspicuously displayed permanent poster (if the contest is conducted by or through a retail outlet) or on each card game piece, entry blank, or other paraphernalia required for participation in the contest (if the contest is not conducted by or through a retail outlet):

(I) the geographical area or number of outlets in which the contest is to be conducted;

(ii) An accurate description of each type of prize;

(iii) The minimum number and minimum amount of cash prizes; and

(iv) The minimum number of each other type of prize; or

(C) that is manipulated or rigged so that prizes are given to predetermined persons or retail establishments. A sales contest is not deceptive if the total value of prizes to each retail outlet is in a uniform ratio to the number of game pieces distributed to that outlet. 
(6) "Mislabeled" means varying from the standard of truth or disclosure in labeling prescribed by law or set by established commercial usage.

(7) "Prize" includes gift, discount, coupon, certificate, gratuity, and any other thing of value awarded in a sales contest.

(8) "Sales contest" means a contest in connection with the sale of a commodity or service by which a person may, as determined by drawing, guessing, matching, or chance, receive a prize and which is not regulated by the rules of a federal regulatory agency.

(9) "Sell" and "sale" include offer for sale, advertise for sale, expose for sale, keep for the purpose of sale, deliver for or after sale, solicit and offer to buy, and every disposition for value. (b) A person commits an offense if in the course of business he intentionally, knowingly, recklessly, or with criminal negligence commits one or more of the following deceptive business practices:

(1) using, selling, or possessing for use or sale a false weight or measure, or any other device for falsely determining or recording any quality or quantity;

(2) Selling less than the represented quantity of a property or service;

(3) Taking more than the represented quantity of property or service when as a buyer the actor furnishes the weight or measure;

(4) Selling an adulterated or mislabeled commodity;

(5) Passing off property or service as that of another;

(6) representing that a commodity is original or new if it is deteriorated, altered, rebuilt, reconditioned, reclaimed, used, or secondhand;

(7) Representing that a commodity or service is of a particular style, grade, or model if it is of another;

(8) Advertising property or service with intent:

(A) Not to sell it as advertised, or

(B) Not to supply reasonably expectable public demand, unless the advertising adequately discloses a time or quantity limit;

(9) Representing the price of property or service falsely or in a way tending to mislead;

(10) Making a materially false or misleading statement of fact concerning the reason for, existence of, or amount of a price or price reduction;

(11) Conducting a deceptive sales contest; or

(12) Making a materially false or misleading statement:

(A) In an advertisement for the purchase or sale of property or service; or

(B) Otherwise in connection with the purchase or sale of property or service.

(c) An offense under Subsections (b) (1), (b) (2), (b) (3), (b) (4),

(b) (5), and (b) (6) is:

(1) A Class $\mathrm{C}$ misdemeanor if the actor commits an offense with criminal negligence and if he has not previously been convicted of a deceptive business practice; or

(2) A Class A misdemeanor if the actor commits an offense intentionally, knowingly, recklessly or if he has been previously convicted of a Class B or C misdemeanor under this section. 
(d) An offense under Subsections (b) (7), (b) (8), (b) (9), (b)

(10), (b) (11), and (b) (12) is a Class A misdemeanor.

SECURING EXECUTION OF DOCUMENT BY DECEPTION

(a) A person commits an offense if, with intent to defraud or harm any person, he, by deception:

(1) Causes another to sign or execute any document affecting property or service or the pecuniary interest of any person; or

(2) Causes or induces a public servant to file or record any purported judgment or other document purporting to memorialize or evidence an act, an order, a directive, or process of:

(A) A purported court that is not expressly created or established under the constitution or the laws of this state or of the United States;

(B) A purported judicial entity that is not expressly created or established under the constitution or laws of this state or of the United States; or

(C) A purported judicial officer of a purported court or purported judicial entity described by Paragraph (A) or (B).

(b) An offense under Subsection (a) (1) is a:

(1) Class $\mathrm{C}$ misdemeanor if the value of the property, service, or pecuniary interest is less than $\$ 20$;

(2) Class B misdemeanor if the value of the property, service, or pecuniary interest is $\$ 20$ or more but less than $\$ 500$;

(3) Class a misdemeanor if the value of the property, service, or pecuniary interest is $\$ 500$ or more but less than $\$ 1,500$;

(4) State jail felony if the value of the property, service, or pecuniary interest is $\$ 1,500$ or more but less than $\$ 20,000$;

(5) Felony of the third degree if the value of the property, service, or pecuniary interest is $\$ 20,000$ or more but less than $\$ 100,000$;

(6) Felony of the second degree if the value of the property, service, or pecuniary interest is $\$ 100,000$ or more but less than $\$ 200,000$; or

(7) Felony of the first degree if the value of the property, service, or pecuniary interest is $\$ 200,000$ or more.

(c) An offense under Subsection (a) (2) is a state jail felony. (C-1) An offense described for purposes of punishment by Subsections (b)(1)-(6) and (c) is increased to the next higher category of offense if it is shown on the trial of the offense that the offense was committed against an elderly individual as defined by Section 22.04.

(d) In this section, "deception" has the meaning assigned by Section 31.01.

(e) With the consent of the appropriate local county or district attorney, the attorney general has concurrent jurisdiction with that consenting local prosecutor to prosecute an offense under this section that involves the state Medicaid program.

FRAUDULENT DESTRUCTION, REMOVAL, OR CONCEALMENT OF WRITING.

(a) A person commits an offense if, with intent to defraud or harm another, he destroys, removes, conceals, alters, substitutes, or otherwise impairs the verity, legibility, or availability of writing, other than a governmental record.

(b) For purposes of this section, "writing" includes:

(1) Printing or any other method of recording information; 
(2) Money, coins, tokens, stamps, seals, credit cards, badges, trademarks;

(3) Symbols of value, right, privilege, or identification; and

(4) Universal product codes, labels, price tags, or markings on goods.

(c) Except as provided in Subsection (d), an offense under this section is a Class a misdemeanor.

(d) An offense under this section is a state jail felony if the writing:

(1) Is a will or codicil of another, whether or not the maker is alive or dead and whether or not it has been admitted to probate; or

(2) Is a deed, mortgage, deed of trust, security instrument, security agreement, or other writing for which the law provides public recording or filing, whether or not the writing has been acknowledged?

\section{REFUSAL TO EXECUTE RELEASE OF FRAUDULENT LIEN OR CLAIM}

(a) A person commits an offense if, with intent to defraud or harm another, the person:

(1) owns, holds, or is the beneficiary of a purported lien or claim asserted against real or personal property or an interest in real or personal property that is fraudulent, as described by Section 51.901(c), Government Code; and

(2) not later than the 21st day after the date of receipt of actual or written notice sent by either certified or registered mail, return receipt requested, to the person's last known address, or by telephonic document transfer to the recipient's current telecopier number, requesting the execution of a release of the fraudulent lien or claim, refuses to execute the release on the request of:

(A) The obligor or debtor; or

(B) Any person who owns any interest in the real or personal property described in the document or instrument that is the basis for the lien or claim.

(b) A person who fails to execute a release of the purported lien or claim within the period prescribed by Subsection (a) (2) is presumed to have had the intent to harm or defraud another.

(c) An offense under this section is a Class A misdemeanor.

DECEPTIVE PREPARATION AND MARKETING OF ACADEMIC PRODUCT

(a) For purposes of this section:

(1) "Academic product" means a term paper, thesis, dissertation, essay, report, recording, work of art, or other written, recorded, pictorial, or artistic product or material submitted or intended to be submitted by a person to satisfy an academic requirement of the person.

(2) "Academic requirement" means a requirement or prerequisite to receive course credit or to complete a course of study or degree, diploma, or certificate program at an institution of higher education.

(3) "Institution of higher education" means an institution of higher education or private or independent institution of higher education as those terms are defined by Section 61.003, Education Code, or a private postsecondary educational institution as that term is defined by Section 61.302, Education Code.

(b) A person commits an offense if, with intent to make a profit, the person prepares, sells, offers or advertises for sale, or delivers to another person an academic product when the person knows, or should reasonably have known, that a person 
intends to submit or use the academic product to satisfy an academic requirement of a person other than the person who prepared the product.

(c) A person commits an offense if, with intent to induce another person to enter into an agreement or obligation to obtain or have prepared an academic product, the person knowingly makes or disseminates a written or oral statement that the person will prepare or cause to be prepared an academic product to be sold for use in satisfying an academic requirement of a person other than the person who prepared the product.

(d) It is a defense to prosecution under this section that the actor's conduct consisted solely of action taken as an employee of an institution of higher education in providing instruction, counseling, or tutoring in research or writing to students of the institution.

(e) It is a defense to prosecution under this section that the actor's conduct consisted solely of offering or providing tutorial or editing assistance to another person in connection with the other person's preparation of an academic product to satisfy the other person's academic requirement, and the actor does not offer or provide substantial preparation, writing, or research in the production of the academic product.

(f) It is a defense to prosecution under this section that the actor's conduct consisted solely of typing, transcribing, or reproducing a manuscript for a fee, or of offering to do so.

(g) An offense under this section is a Class $\mathrm{C}$ misdemeanor.

FRAUDULENT USE OR POSSESSION OF IDENTIFYING INFORMATION

(a) In this section:

(1) "Identifying information" means information that alone or in conjunction with other information identifies an individual, including an individual's:

(A) Name, social security number, date of birth, and government-issued identification number;

(B) Unique biometric data, including the individual's fingerprint, voice print, and retina or iris image;

(C) Unique electronic identification number, address, and routing code, financial institution account number; and

(D) Telecommunication identifying information or access device.

(2) "Telecommunication access device" means a card, plate, code, account number, personal identification number, electronic serial number, mobile identification number, or other telecommunications service, equipment, or instrument identifier or means of account access that alone or in conjunction with another telecommunication access device may be used to:

(A) Obtain money, goods, services, or other thing of value; or

(B) Initiate a transfer of funds other than a transfer originated solely by paper instrument.

(b) A person commits an offense if the person obtains, possesses, transfers, or uses identifying information of another person without the other person's consent and with intent to harm or defraud another.

(c) An offense under this section is a state jail felony.

(d) If a court orders a defendant convicted of an offense under this section to make restitution to the victim of the offense, the court may order the defendant to 
reimburse the victim for lost income or other expenses, other than attorney's fees, incurred as a result of the offense.

(e) If conduct that constitutes an offense under this section also constitutes an offense under any other law, the actor may be prosecuted under this section or the other law.

Fraud under the Islamic criminal law is one of the important crimes and has rigorous punishment; its punishment is jail 1-7 years.

Extortion

Extortion is a criminal offense, which occurs when a person obtains money, behavior, or other goods and/or services from another by wrongfully threatening or inflicting harm to his person, reputation, or property. Euphemistically, refraining from doing harm is sometimes called protection.

Blackmail is one kind of extortion -- specifically, extortion by threatening another's reputation with the disclosure of incriminating statements (true or false) about him. Even if it is not criminal to disclose the information, it constitutes extortion to demand money or other consideration not to disclose it.

Extortion is distinguished from robbery. In robbery, the offender steals goods from the victim whilst threatening him with immediate force. In extortion, the victim willingly turns the goods over to avoid a threatened later violence or other harm.

The term extortion is often used metaphorically to refer to usury or to price-gouging, though neither is legally considered extortion. Some Libertarians and Objectivists have described taxation as a form of "extortion". The great increase in often-frivolous lawsuits in recent times has led to situations where some feel that others are abusing the legal system in their own extortion schemes, threatening to sue (for instance over alleged trademark infringement or defamation) in cases where the prospective defendant did no wrong, but feels compelled to settle and make a payment anyway to avoid expensive litigation.

The United States defines extortion as: The term "extortion" means the obtaining of property from another, with his consent, induced by wrongful use of actual or threatened force, violence, or fear, or under color of official right.

This one happened in Islamic Republic of Iran so much; because there are people don't have enough social instruction and their relation adherence of violence also economic problems made people to try earn money by each way.

Forgery

Forgery is the process of making or adapting objects or documents (see false document), with the intention to deceive. The similar crime of fraud is the crime of deceiving another, including through the use of objects obtained through forgery. Copies, studio replicas, and reproductions are not considered forgeries, though they may later become forgeries through knowing and willful mis-attributions. In the 16th century imitators of Albrecht Dürer's style of printmaking improved the market for their own prints by signing them "AD", making them forgeries.

In the 20th century the art market made forgeries highly profitable. There are widespread forgeries of especially valued artists, such as drawings meant to be by Picasso, Klee, and Matisse.

This usage of 'forgery' does not derive from metalwork done at a 'forge', but it has a parallel history. A sense of "to counterfeit" is already in the Anglo-French verb forger "falsify." 
Forgery is one of the techniques of fraud, including identity theft. Forgery is one of the threats that have to be addressed by security engineering.

A forgery is essentially concerned with a produced or altered object. Where the prime concern of a forgery is less focused on the object itself - what it is worth or what it "proves" - than on a tacit statement of criticism that is revealed by the reactions the object provokes in others, then the larger process is a hoax. In a hoax, a cultural meme, such as a rumor, or a genuine object "planted" in a concocted situation, may substitute for a forged physical object.

This crime under the Islamic criminal law is one of the crimes against justice and punishment for it may be jail or in some cases may be gallows. If forgery related to leader or president doer convict to gallows; But rigorous punishment don't effect on increase of it in Islamic republic of Iran.

CRIMINAL SIMULATION

(a) A person commits an offense if, with intent to defraud or harm another:

(1) he makes or alters an object, in whole or in part, so that it appears to have value because of age, antiquity, rarity, source, or authorship that it does not have;

(2) he possesses an object so made or altered, with intent to sell, pass, or otherwise utter it; or

(3) He authenticates or certifies an object so made or altered as genuine or as different from what it is.

(b) An offense under this section is a Class A misdemeanor.

TRADEMARK COUNTERFEITING

(a) In this section:

(1) "Counterfeit mark" means a mark that is identical to or substantially indistinguishable from a protected mark the use or production of which is not authorized by the owner of the protected mark.

(2) "Identification mark" means a data plate, serial number, or part identification number.

(3) "Protected mark" means a trademark or service mark or an identification mark that is:

(A) Registered with the secretary of state;

(B) Registered on the principal register of the United States Patent and Trademark Office;

(C) Registered under the laws of another state; or

(D) Protected by Section 16.30, Business \& Commerce Code, or by 36 U.S.C. Section 371 et seq.

(4) "Retail value" means the actor's regular selling price for a counterfeit mark or an item or service that bears or is identified by a counterfeit mark, except that if an item bearing a counterfeit mark is a component of a finished product, the retail value means the actor's regular selling price of the finished product on or in which the component is used, distributed, or sold.

(5) "Service mark" has the meaning assigned by Section 16.01, Business \& Commerce Code.

(6) "Trademark" has the meaning assigned by Section 16.01, Business \& Commerce Code.

(b) A person commits an offense if the person intentionally manufactures, displays, advertises, distributes, offers for sale, sells, or possesses with intent to sell or distribute a counterfeit mark or an item or service that: 
(1) Bears or is identified by a counterfeit mark; or

(2) The person knows or should have known bears or is identified by a counterfeit mark.

(c) A state or federal certificate of registration of intellectual property is prima facie evidence of the facts stated in the certificate.

(d) For the purposes of Subsection (e), when items or services are the subject of counterfeiting in violation of this section pursuant to one scheme or continuing course of conduct, the conduct may be considered as one offense and the retail value of the items or services aggregated in determining the grade of offense. (e) An offense under this section is a:

(1) Class $\mathrm{C}$ misdemeanor if the retail value of the item or service is less than $\$ 20$;

(2) Class B misdemeanor if the retail value of the item or service is $\$ 20$ or more but less than $\$ 500$;

(3) Class a misdemeanor if the retail value of the item or service is $\$ 500$ or more but less than $\$ 1,500$;

(4) State jail felony if the retail value of the item or service is $\$ 1,500$ or more but less than $\$ 20,000$;

(5) Felony of the third degree if the retail value of the item or service is $\$ 20,000$ or more but less than $\$ 100,000$;

(6) Felony of the second degree if the retail value of the item or service is $\$ 100,000$ or more but less than $\$ 200,000$; or

(7) Felony of the first degree if the retail value of the item or service is $\$ 200,000$ or more.

Added by Acts 1997, 75th Leg., ch. 1161, Sec. 2, eff. Sept. 1, 1997. CREDIT CARD OR DEBIT CARD ABUSE (a) For purposes of this section:

(1) "Cardholder" means the person named on the face of a credit card or debit card to whom or for whose benefit the card is issued.

(2) "Credit card" means an identification card, plate, coupon, book, number, or any other device authorizing a designated person or bearer to obtain property or services on credit. The term includes the number or description of the device if the device itself is not produced at the time of ordering or obtaining the property or service.

(3) "Expired credit card" means a credit card bearing an expiration date after that date has passed.

(4) "Debit card" means an identification card, plate, coupon, book, number, or any other device authorizing a designated person or bearer to communicate a request to an unmanned teller machine or a customer convenience terminal or obtain property or services by debit to an account at a financial institution. The term includes the number or description of the device if the device itself is not produced at the time of ordering or obtaining the benefit.

(5) "Expired debit card" means a debit card bearing as its expiration date a date that has passed.

(6) "Unmanned teller machine" means a machine, other than a telephone, capable of being operated by a customer, by which a customer may communicate to a financial institution a request to withdraw a benefit for himself or for another directly from the customer's account or from the customer's account under a line of credit previously authorized by the institution for the customer. 
(7) "Customer convenience terminal" means an unmanned teller machine the use of which does not involve personnel of a financial institution. (b) A person commits an offense if:

(1) With intent to obtain a benefit fraudulently, he presents or uses a credit card or debit card with knowledge that:

(A) The card, whether or not expired, has not been issued to him and is not used with the effective consent of the cardholder; or

(B) The card has expired or has been revoked or cancelled;

(2) With intent to obtain a benefit, he uses a fictitious credit card or debit card or the pretended number or description of a fictitious card;

(3) He receives a benefit that he knows has been obtained in violation of this section;

(4) he steals a credit card or debit card or, with knowledge that it has been stolen, receives a credit card or debit card with intent to use it, to sell it, or to transfer it to a person other than the issuer or the cardholder;

(5) He buys a credit card or debit card from a person who he knows is not the issuer;

(6) Not being the issuer, he sells a credit card or debit card;

(7) he uses or induces the cardholder to use the cardholder's credit card or debit card to obtain property or service for the actor's benefit for which the cardholder is financially unable to pay;

(8) Not being the cardholder, and without the effective consent of the cardholder, he possesses a credit card or debit card with intent to use it;

(9) He possesses two or more incomplete credit cards or debit cards that have not been issued to him with intent to complete them without the effective consent of the issuer. For purposes of this subdivision, a card is incomplete if part of the matter that an issuer

requires to appear on the card before it can be used, other than the signature of the cardholder, has not yet been stamped, embossed, imprinted, or written on it;

(10) being authorized by an issuer to furnish goods or services on presentation of a credit card or debit card, he, with intent to defraud the issuer or the cardholder, furnishes goods or services on presentation of a credit card or debit card obtained or retained in violation of this section or a credit card or debit card that is forged, expired, or revoked; or

(11) being authorized by an issuer to furnish goods or services on presentation of a credit card or debit card, he, with intent to defraud the issuer or a cardholder, fails to furnish goods or services that he represents in writing to the issuer that he has furnished.

(c) It is presumed that a person who used a revoked, cancelled, or expired credit card or debit card had knowledge that the card had been revoked, cancelled, or expired if he had received notice of revocation, cancellation, or expiration from the issuer. For purposes of this section, notice may be either notice given orally in person or by telephone, or in writing by mail or by telegram. If written notice was sent by registered or certified mail with return receipt requested, or by telegram with report of delivery requested, addressed to the cardholder at the last address shown by the records of the issuer, it is presumed that the notice was received by the cardholder no later than five days after sent. 
(d) An offense under this section is a state jail felony. HINDERING SECURED CREDITORS

(a) For purposes of this section:

(1) "Remove" means transport, without the effective consent of the secured party, from the state in which the property was located when the security interest or lien attached.

(2) "Security interest" means an interest in personal property or fixtures that secures payment or performance of an obligation.

(b) A person who has signed a security agreement creating a security interest in property or a mortgage or deed of trust creating a lien on property commits an offense if, with intent to hinder enforcement of that interest or lien, he destroys, removes, conceals, encumbers, or otherwise harms or reduces the value of the property.

(c) For purposes of this section, a person is presumed to have intended to hinder enforcement of the security interest or lien if, when any part of the debt secured by the security interest or lien was due, he failed:

(1) To pay the part then due; and

(2) If the secured party had made demand, to deliver possession of the secured property to the secured party. (d) An offense under Subsection (b) is a:

(1) Class C misdemeanor if the value of the property destroyed, removed, concealed, encumbered, or otherwise harmed or reduced in value is less than $\$ 20$;

(2) Class B misdemeanor if the value of the property destroyed, removed, concealed, encumbered, or otherwise harmed or reduced in value is $\$ 20$ or more but less than $\$ 500$;

(3) Class A misdemeanor if the value of the property destroyed, removed, concealed, encumbered, or otherwise harmed or reduced in value is $\$ 500$ or more but less than $\$ 1,500$;

(4) state jail felony if the value of the property destroyed, removed, concealed, encumbered, or otherwise harmed or reduced in value is $\$ 1,500$ or more but less than $\$ 20,000$;

(5) felony of the third degree if the value of the property destroyed, removed, concealed, encumbered, or otherwise harmed or reduced in value is $\$ 20,000$ or more but less than $\$ 100,000$;

(6) felony of the second degree if the value of the property destroyed, removed, concealed, encumbered, or otherwise harmed or reduced in value is $\$ 100,000$ or more but less than $\$ 200,000$; or

(7) Felony of the first degree if the value of the property destroyed, removed, concealed, encumbered, or otherwise harmed or reduced in value is $\$ 200,000$ or more.

(e) A person who is a debtor under a security agreement, and who does not have a right to sell or dispose of the secured property or is required to account to the secured party for the proceeds of a permitted sale or disposition, commits an offense if the person sells or otherwise disposes of the secured property, or does not account to the secured party for the proceeds of a sale or other disposition as required, with intent to appropriate (as defined in Chapter 31) the proceeds or value of the secured property. A person is presumed to have intended to appropriate proceeds if the person does not deliver the proceeds to the secured party or account to the secured party for the proceeds before the 11th day after the day that the secured party makes a lawful demand for the proceeds or account. An offense under this subsection is: 
(1) A Class $\mathrm{C}$ misdemeanor if the proceeds obtained from the sale or other disposition is money or goods having a value of less than $\$ 20$;

(2) A Class B misdemeanor if the proceeds obtained from the sale or other disposition are money or goods having a value of $\$ 20$ or more but less than $\$ 500$;

(3) A Class A misdemeanor if the proceeds obtained from the sale or other disposition are money or goods having a value of $\$ 500$ or more but less than $\$ 1,500$;

(4) A state jail felony if the proceeds obtained from the sale or other disposition is money or goods having a value of $\$ 1,500$ or more but less than $\$ 20,000$;

(5) a felony of the third degree if the proceeds obtained from the sale or other disposition are money or goods having a value of $\$ 20,000$ or more but less than $\$ 100,000$;

(6) a felony of the second degree if the proceeds obtained from the sale or other disposition are money or goods having a value of $\$ 100,000$ or more but less than $\$ 200,000$; or

(7) A felony of the first degree if the proceeds obtained from the sale or other disposition is money or goods having a value of $\$ 200,000$ or more.

CREDIT CARD TRANSACTION RECORD LAUNDERING (a) In this section:

(1) "Agent" means a person authorized to act on behalf of another and includes an employee.

(2) "Authorized vendor" means a person authorized by a creditor to furnish property, service, or anything else of value upon presentation of a credit card by a cardholder.

(3) "Cardholder" means the person named on the face of a credit card to whom or for whose benefit the credit card is issued, and includes the named person's agents.

(4) "Credit card" means an identification card, plate, coupon, book, number, or any other device authorizing a designated person or bearer to obtain property or services on credit. It includes the number or description on the device if the device itself is not produced at the time of ordering or obtaining the property or service.

(5) "Creditor" means a person licensed under Chapter 342, Finance Code, a bank, savings and loan association, credit union, or other regulated financial institution that lends money or otherwise extends credit to a cardholder through a credit card and that authorizes other persons to honor the credit card.

(b) A person commits an offense if the person is an authorized vendor who, with intent to defraud the creditor or cardholder, presents to a creditor, for payment, a credit card transaction record of a sale that was not made by the authorized vendor or the vendor's agent.

(c) A person commits an offense if, without the creditor's authorization, the person employs, solicits, or otherwise causes an authorized vendor or the vendor's agent to present to a creditor, for payment, a credit card transaction record of a sale that was not made by the authorized vendor or the vendor's agent.

(d) It is presumed that a person is not the agent of an authorized vendor if a fee is paid or offered to be paid by the person to the authorized vendor in connection with the vendor's presentment to a creditor of a credit card transaction record.

(e) An offense under this section is a:

(1) Class C misdemeanor if the amount of the record of a sale is less than $\$ 20$; 
(2) Class B misdemeanor if the amount of the record of a sale is $\$ 20$ or more but less than $\$ 500$;

(3) Class a misdemeanor if the amount of the record of a sale is $\$ 500$ or more but less than $\$ 1,500$;

(4) State jail felony if the amount of the record of a sale is $\$ 1,500$ or more but less than $\$ 20,000$;

(5) Felony of the third degree if the amount of the record of a sale is $\$ 20,000$ or more but less than $\$ 100,000$;

(6) Felony of the second degree if the amount of the record of a sale is $\$ 100,000$ or more but less than $\$ 200,000$; or

(7) Felony of the first degree if the amount of the record of a sale is $\$ 200,000$ or more. SIMULATING LEGAL PROCESS

(a) A person commits an offense if the person recklessly causes to be delivered to another any document that simulates a summons, complaint, judgment, or other court process with the intent to:

(1) Induce payment of a claim from another person; or

(2) Cause another to:

(A) Submit to the putative authority of the document; or

(B) Take any action or refrain from taking any action in response to the document, in compliance with the document, or on the basis of the document.

(b) Proof that the document was mailed to any person with the intent that it be forwarded to the intended recipient is a sufficient showing that the document was delivered.

(c) It is not a defense to prosecution under this section that the simulating document:

(1) States that it is not legal process; or

(2) Purports to have been issued or authorized by a person or entity that did not have lawful authority to issue or authorize the document.

(d) If it is shown on the trial of an offense under this section that the simulating document was filed with, presented to, or delivered to a clerk of a court or an employee of a clerk of a court created or established under the constitution or laws of this state, there is a rebutable presumption that the document was delivered with the intent described by Subsection (a).

(e) Except as provided by Subsection (f), an offense under this section is a Class A misdemeanor.

(f) If it is shown on the trial of an offense under this section that the defendant has previously been convicted of a violation of this section, the offense is a state jail felony. FRAUDULENT, SUBSTANDARD, OR FICTITIOUS DEGREE

(a) In this section, "fraudulent or substandard degree" has the meaning assigned by Section 61.302, Education Code.

(b) A person commits an offense if the person:

(1) Uses or claims to hold a postsecondary degree that the person knows:

(A) Is a fraudulent or substandard degree?

(B) is fictitious or has otherwise not been granted to the person; or 
(C) Has been revoked; and

(2) Uses or claims to hold that degree:

(A) In a written or oral advertisement or other promotion of a business; or

(B) With the intent to: (I) obtain employment; (ii) Obtain a license or certificate to practice a trade, profession, or occupation; (iii) Obtain a promotion, compensation or other benefit, or an increase in compensation or other benefit, in employment or in the practice of a trade, profession, or occupation; (iv) Obtain admission to an educational program in this state; or

(v) Gain a position in government with authority over another person, regardless of whether the actor receives compensation for the position.

(c) An offense under this section is a Class B misdemeanor.

(d) If conduct that constitutes an offense under this section also constitutes an offense under any other law, the actor may be prosecuted under this section or the other law. CRIMINAL SIMULATION

(a) A person commits an offense if, with intent to defraud or harm another:

(1) he makes or alters an object, in whole or in part, so that it appears to have value because of age, antiquity, rarity, source, or authorship that it does not have;

(2) he possesses an object so made or altered, with intent to sell, pass, or otherwise utter it; or

(3) He authenticates or certifies an object so made or altered as genuine or as different from what it is.

(b) An offense under this section is a Class A misdemeanor.

TRADEMARK COUNTERFEITING

(a) In this section:

(1) "Counterfeit mark" means a mark that is identical to or substantially indistinguishable from a protected mark the use or production of which is not authorized by the owner of the protected mark.

(2) "Identification mark" means a data plate, serial number, or part identification number.

(3) "Protected mark" means a trademark or service mark or an identification mark that is:

(A) Registered with the secretary of state;

(B) Registered on the principal register of the United States Patent and Trademark Office;

(C) Registered under the laws of another state; or

(D) Protected by Section 16.30, Business \& Commerce Code, or by 36 U.S.C. Section 371 et seq.

(4) "Retail value" means the actor's regular selling price for a counterfeit mark or an item or service that bears or is identified by a counterfeit mark, except that if an item bearing a counterfeit mark is a component of a finished product, the retail value means the actor's regular selling price of the finished product on or in which the component is used, distributed, or sold.

(5) "Service mark" has the meaning assigned by Section 16.01, Business \& Commerce Code.

(6) "Trademark" has the meaning assigned by Section 16.01, Business \& Commerce Code. 
(b) A person commits an offense if the person intentionally manufactures, displays, advertises, distributes, offers for sale, sells, or possesses with intent to sell or distribute a counterfeit mark or an item or service that:

(1) Bears or is identified by a counterfeit mark; or

(2) The person knows or should have known bears or is identified by a counterfeit mark.

(c) A state or federal certificate of registration of intellectual property is prima facie evidence of the facts stated in the certificate.

(d) For the purposes of Subsection (e), when items or services are the subject of counterfeiting in violation of this section pursuant to one scheme or continuing course of conduct, the conduct may be considered as one offense and the retail value of the items or services aggregated in determining the grade of offense.

(e) An offense under this section is a: (1) Class $\mathrm{C}$ misdemeanor if the retail value of the item or service is less than $\$ 20$;

(2) Class B misdemeanor if the retail value of the item or service is $\$ 20$ or more but less than $\$ 500$;

(3) Class a misdemeanor if the retail value of the item or service is $\$ 500$ or more but less than $\$ 1,500$;

(4) State jail felony if the retail value of the item or service is $\$ 1,500$ or more but less than $\$ 20,000$;

(5) Felony of the third degree if the retail value of the item or service is $\$ 20,000$ or more but less than $\$ 100,000$;

(6) Felony of the second degree if the retail value of the item or service is $\$ 100,000$ or more but less than $\$ 200,000$; or

(7) Felony of the first degree if the retail value of the item or service is $\$ 200,000$ or more. Added by Acts 1997, 75th Leg., ch. 1161, Sec. 2, eff. Sept. 1, 1997.

CREDIT CARD OR DEBIT CARD ABUSE (a) For purposes of this section:

(1) "Cardholder" means the person named on the face of a credit card or debit card to whom or for whose benefit the card is issued.

(2) "Credit card" means an identification card, plate, coupon, book, number, or any other device authorizing a designated person or bearer to obtain property or services on credit. The term includes the number or description of the device if the device itself is not produced at the time of ordering or obtaining the property or service.

(3) "Expired credit card" means a credit card bearing an expiration date after that date has passed.

(4) "Debit card" means an identification card, plate, coupon, book, number, or any other device authorizing a designated person or bearer to communicate a request to an unmanned teller machine or a customer convenience terminal or obtain property or services by debit to an account at a financial institution. The term includes the number or description of the device if the device itself is not produced at the time of ordering or obtaining the benefit.

(5) "Expired debit card" means a debit card bearing as its expiration date a date that has passed.

(6) "Unmanned teller machine" means a machine, other than a telephone, capable of being operated by a customer, by which a customer may communicate to a financial institution a request to withdraw a benefit for himself or for another directly 
from the customer's account or from the customer's account under a line of credit previously authorized by the institution for the customer.

(7) "Customer convenience terminal" means an unmanned teller machine the use of which does not involve personnel of a financial institution.

(b) A person commits an offense if:

(1) With intent to obtain a benefit fraudulently, he presents or uses a credit card or debit card with knowledge that:

(A) The card, whether or not expired, has not been issued to him and is not used with the effective consent of the cardholder; or

(B) The card has expired or has been revoked or cancelled;

(2) With intent to obtain a benefit, he uses a fictitious credit card or debit card or the pretended number or description of a fictitious card;

(3) He receives a benefit that he knows has been obtained in violation of this section;

(4) he steals a credit card or debit card or, with knowledge that it has been stolen, receives a credit card or debit card with intent to use it, to sell it, or to transfer it to a person other than the issuer or the cardholder;

(5) He buys a credit card or debit card from a person who he knows is not the issuer;

(6) Not being the issuer, he sells a credit card or debit card;

(7) he uses or induces the cardholder to use the cardholder's credit card or debit card to obtain property or service for the actor's benefit for which the cardholder is financially unable to pay;

(8) Not being the cardholder, and without the effective consent of the cardholder, he possesses a credit card or debit card with intent to use it;

(9) He possesses two or more incomplete credit cards or debit cards that have not been issued to him with intent to complete them without the effective consent of the issuer. For purposes of this subdivision, a card is incomplete if part of the matter that an issuer requires to appear on the card before it can be used, other than the signature of the cardholder, has not yet been stamped, embossed, imprinted, or written on it;

(10) being authorized by an issuer to furnish goods or services on presentation of a credit card or debit card, he, with intent to defraud the issuer or the cardholder, furnishes goods or services on presentation of a credit card or debit card obtained or retained in violation of this section or a credit card or debit card that is forged, expired, or revoked; or

(11) being authorized by an issuer to furnish goods or services on presentation of a credit card or debit card, he, with intent to defraud the issuer or a cardholder, fails to furnish goods or services that he represents in writing to the issuer that he has furnished.

(c) It is presumed that a person who used a revoked, cancelled, or expired credit card or debit card had knowledge that the card had been revoked, cancelled, or expired if he had received notice of revocation, cancellation, or expiration from the issuer. For purposes of this section, notice may be either notice given orally in person or by telephone, or in writing by mail or by telegram. If written notice was sent by registered or certified mail with return receipt requested, or by telegram with report of delivery requested, addressed to the cardholder at the last address shown by the 
records of the issuer, it is presumed that the notice was received by the cardholder no later than five days after sent.

(d) An offense under this section is a state jail felony. HINDERING SECURED CREDITORS

(a) For purposes of this section:

(1) "Remove" means transport, without the effective consent of the secured party, from the state in which the property was located when the security interest or lien attached.

(2) "Security interest" means an interest in personal property or fixtures that secures payment or performance of an obligation.

(b) A person who has signed a security agreement creating a security interest in property or a mortgage or deed of trust creating a lien on property commits an offense if, with intent to hinder enforcement of that interest or lien, he destroys, removes, conceals, encumbers, or otherwise harms or reduces the value of the property.

(c) For purposes of this section, a person is presumed to have intended to hinder enforcement of the security interest or lien if, when any part of the debt secured by the security interest or lien was due, he failed:

(1) To pay the part then due; and

(2) If the secured party had made demand, to deliver possession of the secured property to the secured party.

(d) An offense under Subsection (b) is a:

(1) Class C misdemeanor if the value of the property destroyed, removed, concealed, encumbered, or otherwise harmed or reduced in value is less than $\$ 20$;

(2) Class B misdemeanor if the value of the property destroyed, removed, concealed, encumbered, or otherwise harmed or reduced in value is $\$ 20$ or more but less than $\$ 500$;

(3) Class A misdemeanor if the value of the property destroyed, removed, concealed, encumbered, or otherwise harmed or reduced in value is $\$ 500$ or more but less than $\$ 1,500$;

(4) state jail felony if the value of the property destroyed, removed, concealed, encumbered, or otherwise harmed or reduced in value is $\$ 1,500$ or more but less than $\$ 20,000$;

(5) felony of the third degree if the value of the property destroyed, removed, concealed, encumbered, or otherwise harmed or reduced in value is $\$ 20,000$ or more but less than $\$ 100,000$;

(6) felony of the second degree if the value of the property destroyed, removed, concealed, encumbered, or otherwise harmed or reduced in value is $\$ 100,000$ or more but less than $\$ 200,000$; or

(7) Felony of the first degree if the value of the property destroyed, removed, concealed, encumbered, or otherwise harmed or reduced in value is $\$ 200,000$ or more.

(e) A person who is a debtor under a security agreement, and who does not have a right to sell or dispose of the secured property or is required to account to the secured party for the proceeds of a permitted sale or disposition, commits an offense if the person sells or otherwise disposes of the secured property, or does not account to the secured party for the proceeds of a sale or other disposition as required, with intent to 
appropriate (as defined in Chapter 31) the proceeds or value of the secured property. A person is presumed to have intended to appropriate proceeds if the person does not deliver the proceeds to the secured party or account to the secured party for the proceeds before the 11th day after the day that the secured party makes a lawful demand for the proceeds or account. An offense under this subsection is:

(1) A Class $\mathrm{C}$ misdemeanor if the proceeds obtained from the sale or other disposition is money or goods having a value of less than $\$ 20$;

(2) A Class B misdemeanor if the proceeds obtained from the sale or other disposition are money or goods having a value of $\$ 20$ or more but less than $\$ 500$;

(3) A Class A misdemeanor if the proceeds obtained from the sale or other disposition are money or goods having a value of $\$ 500$ or more but less than $\$ 1,500$;

(4) A state jail felony if the proceeds obtained from the sale or other disposition is money or goods having a value of $\$ 1,500$ or more but less than $\$ 20,000$;

(5) a felony of the third degree if the proceeds obtained from the sale or other disposition are money or goods having a value of $\$ 20,000$ or more but less than $\$ 100,000$;

(6) a felony of the second degree if the proceeds obtained from the sale or other disposition are money or goods having a value of $\$ 100,000$ or more but less than $\$ 200,000$; or

(7) A felony of the first degree if the proceeds obtained from the sale or other disposition is money or goods having a value of $\$ 200,000$ or more.

CREDIT CARD TRANSACTION RECORD LAUNDERING (a) In this section:

(1) "Agent" means a person authorized to act on behalf of another and includes an employee.

(2) "Authorized vendor" means a person authorized by a creditor to furnish property, service, or anything else of value upon presentation of a credit card by a cardholder.

(3) "Cardholder" means the person named on the face of a credit card to whom or for whose benefit the credit card is issued, and includes the named person's agents.

(4) "Credit card" means an identification card, plate, coupon, book, number, or any other device authorizing a designated person or bearer to obtain property or services on credit. It includes the number or description on the device if the device itself is not produced at the time of ordering or obtaining the property or service.

(5) "Creditor" means a person licensed under Chapter 342, Finance Code, a bank, savings and loan association, credit union, or other regulated financial institution that lends money or otherwise extends credit to a cardholder through a credit card and that authorizes other persons to honor the credit card. (b) A person commits an offense if the person is an authorized vendor who, with intent to defraud the creditor or cardholder, presents to a creditor, for payment, a credit card transaction record

of a sale that was not made by the authorized vendor or the vendor's agent.

(c) A person commits an offense if, without the creditor's authorization, the person employs, solicits, or otherwise causes an authorized vendor or the vendor's agent to present to a creditor, for payment, a credit card transaction record of a sale that was not made by the authorized vendor or the vendor's agent.

(d) It is presumed that a person is not the agent of an authorized vendor if a fee is paid or offered to be paid by the person to the authorized vendor in connection with the vendor's presentment to a creditor of a credit card transaction record. 
(e) An offense under this section is a:

(1) Class $\mathrm{C}$ misdemeanor if the amount of the record of a sale is less than $\$ 20$;

(2) Class B misdemeanor if the amount of the record of a sale is $\$ 20$ or more but less than $\$ 500$;

(3) Class a misdemeanor if the amount of the record of a sale is $\$ 500$ or more but less than $\$ 1,500$;

(4) State jail felony if the amount of the record of a sale is $\$ 1,500$ or more but less than $\$ 20,000$;

(5) Felony of the third degree if the amount of the record of a sale is $\$ 20,000$ or more but less than $\$ 100,000$;

(6) Felony of the second degree if the amount of the record of a sale is $\$ 100,000$ or more but less than $\$ 200,000$; or

(7) Felony of the first degree if the amount of the record of a sale is $\$ 200,000$ or more. SIMULATING LEGAL PROCESS

(a) A person commits an offense if the person recklessly causes to be delivered to another any document that simulates a summons, complaint, judgment, or other court process with the intent to:

(1) Induce payment of a claim from another person; or

(2) Cause another to:

(A) Submit to the putative authority of the document; or

(B) Take any action or refrain from taking any action in response to the document, in compliance with the document, or on the basis of the document.

(b) Proof that the document was mailed to any person with the intent that it be forwarded to the intended recipient is a sufficient showing that the document was delivered.

(c) It is not a defense to prosecution under this section that the simulating document:

(1) States that it is not legal process; or

(2) Purports to have been issued or authorized by a person or entity that did not have lawful authority to issue or authorize the document.

(d) If it is shown on the trial of an offense under this section that the simulating document was filed with, presented to, or delivered to a clerk of a court or an employee of a clerk of a court created or established under the constitution or laws of this state, there is a rebuttable presumption that the document was delivered with the intent described by Subsection (a).

(e) Except as provided by Subsection (f), an offense under this section is a Class A misdemeanor.

(f) If it is shown on the trial of an offense under this section that the defendant has previously been convicted of a violation of this section, the offense is a state jail felony. FRAUDULENT, SUBSTANDARD, OR FICTITIOUS DEGREE

(a) In this section, "fraudulent or substandard degree" has the meaning assigned by Section 61.302, Education Code.

(b) A person commits an offense if the person:

(1) Uses or claims to hold a postsecondary degree that the person knows: 
(A) Is a fraudulent or substandard degree?

(B) is fictitious or has otherwise not been granted to the person; or

(C) Has been revoked; and

(2) Uses or claims to hold that degree:

(A) In a written or oral advertisement or other promotion of a business; or

(B) With the intent to: (I) obtain employment; (ii) Obtain a license or certificate to practice a trade, profession, or occupation; (iii) Obtain a promotion, compensation or other benefit, or an increase in compensation or other benefit, in employment or in the practice of a trade, profession, or occupation; (iv) Obtain admission to an educational program in this state; or (v) Gain a position in government with authority over another person, regardless of whether the actor receives compensation for the position.

(c) An offense under this section is a Class B misdemeanor.

(d) If conduct that constitutes an offense under this section also constitutes an offense under any other law, the actor may be prosecuted under this section or the other law. 